\title{
Geology and petrology of the Salto do Céu Suite: tectonic and stratigraphic implications on the SW Amazonian Craton
}

\author{
Gabrielle Aparecida de Lima ${ }^{1,2}$ (D), Moacir José Buenano Macambira ${ }^{3}$, \\ Maria Zélia Aguiar de Sousa ${ }^{4}$, Amarildo Salina Ruiz ${ }^{4}$, \\ Maria Elisa Fróes Batata ${ }^{5}$, Ronaldo Pierosan ${ }^{4}$
}

\begin{abstract}
The basic rocks of the Salto do Céu Suite outcrop as sills and flows in the southwestern Amazon Craton, Rondonian-San Ignacio Province, with an age of about $1.44 \mathrm{Ga}$. Sills are 2 to $30 \mathrm{~m}$ thick being hosted by pelites of the Aguapei Group. The flows are up to $5 \mathrm{~m}$ thick and cover this unit. Typical textures of magma mingling are observed near the contact with granites of Rio Branco Suite. The Rio Branco Intrusive Suite is composed of basic and acid rocks, as well as hybrid rocks that indicate mixing processes between basic and acids magmas. U-Pb (TIMS zircon) results indicate ages around $1.4 \mathrm{Ga}$ for both terms. The Salto do Céu Suite rocks have tholeiites affinity classified as subalkaline and iron-rich tholeiitic basalts, with mg\# values between 0.30 and 0.51 . They can be separated into two groups, based on $L a_{N^{\circ}}$ one is richer in ETR with La greater than 100, while the other one has $L a_{N}$ less than 100. Rocks of the Salto do Céu Suite and Rio Branco Suite are interpreted as a bimodal suites showing magma mingling features such as those developed in continental intraplate settings, extensional regime associated to the Columbia/Nuna breakup.
\end{abstract}

KEYWORDS: mafic flows and sills; petrogenesis; extensional tectonics; Amazonian Craton.

\section{INTRODUCTION}

The mafic sills found in the region of Salto do Céu municipality, state of Mato Grosso, central Brazil, belonging to the Salto do Céu Suite (SCS) are interpreted as a record of the breakup of the Rodinia Supercontinent (Ruiz et al. 2010a, Lima et al. 2012) on the basis of K-Ar analyses that yields a cooling age around 0.9 Ga (Barros et al. 1982). Recent U-Pb (TIMS) analyses on baddeleyite show crystallisation ages around $1.44 \mathrm{Ga}$ (Teixeira et al. 2016). This new geochronological result challenges the widely accepted geological history of the SW Amazonian Craton both in terms of this magmatic event of basic nature as well as the age of its country rock, that is, the Aguapeí Group. Distensive magmatic events, with ages similar to those obtained for the Salto do Céu Suite, have been associated with the evolution of the Columbia Supercontinent by many authors (Ernst et al. 2008, 2013, Rogers \& Santosh 2002).

The Rio Branco Intrusive Suite comprises basic (gabbro, diabase and basalt) and felsic (porphyritic and rapakivi granite) rocks. Hybrid rocks (monzosyenite) with rapakivi-like textures indicate commingling and mixing among basic and felsic magmas. U-Pb isotopic data indicate ages close to $1.4 \mathrm{Ga}$ for both terms (Geraldes et al. 2004), situated in the Rondonian-San Ignacio geochronological province (Bettencourt et al. 2010).

Based on field work and new geochronological data available in the literature, as well as in unpublished petrographic and geochemical results of rocks from the SCS, the petrogenetic evolution of this mafic magmatism is discussed,

\footnotetext{
${ }^{1}$ Postgraduate Program in Geology and Geochemistry, Geosciences Institute, Universidade Federal do Pará - Belém (PA), Brazil. E-mail: gabilimagel@gmail.com ²Engineering Institute, Universidade Federal de Mato Grosso - Cuiabá (MT), Brazil.

${ }^{3}$ Laboratory of Isotope Geology, Geosciences Institute, Universidade Federal do Pará - Belém (PA), Brazil. E-mail: moamac@ufpa.br ${ }^{4}$ Geosciences Faculty, Universidade Federal de Mato Grosso - Cuiabá (MT), Brazil. E-mails: prof.mzaguiar@gmail.com, asruiz@gmail.com, ronaldo.pierosan@gmail.com ${ }^{5}$ Postgraduate Program in Geosciences (Mineralogy and Petrology), Geosciences Institute, Universidade de São Paulo - São Paulo (SP), Brazil. E-mail: elisabatata@hotmail.com

Manuscript ID: 20160088. Received on: 07/18/2016. Approved on: 06/29/2018.
} 
as well as its relationship to felsic rocks of the Rio Branco Intrusive Suite (RBIS), and its tectonic implication to the evolution of the southwestern Amazonian Craton.

\section{REGIONAL GEOLOGICAL SETTINGS}

The south-southwest portion of the Amazonian Craton records a widespread occurrence of mafic sills and dyke swarms (Fig. 1) which have been interpreted as evidence for the breakup of the Rodinia Supercontinent (Ruiz et al. 2010a, Sécolo et al. 2011, Lima 2011, Lima et al. 2012).

Gabbros and diabases found in the regions of Salto do Céu and Rio Branco, southwest of the Brazilian state of Mato Grosso, were first reported by Oliva (1979), and later attributed to the Rio Branco Group by Barros et al. (1982). Leite et al. (1985) have attributed this exposure of mesocratic and melanocratic rocks of the Rio Branco Intrusive
Suite to windows in the Vale da Promissao Formation cut by erosion. Therefore, these rocks are described as a differentiated stratiform igneous complex with typical bimodal character, which may be an indicative of anorogenic magmatism likely developed in rift settings.

According to Geraldes (2000) and Geraldes et al. (2001, 2004), the basal portion of the Rio Branco Intrusive Suite is composed of basic rocks, while its upper portion comprises a plutonic-volcanic association chiefly composed of acid to intermediate rocks. These authors presented a U-Pb age of $1471 \pm 8 \mathrm{Ma}$ for basic rocks, and an age of $1427 \pm 10 \mathrm{Ma}$ for acid rocks that are interpreted as an extensional intracratonic magmatism, a reflection of the Santa Helena magmatic arc (1.47-1.42 Ga).

The Santa Helena magmatic arc is characterized in a precocious phase (1480-1485 Ma) by calc-alkaline batholiths, peraluminous, tonalitic and monzogranitic (Santa Helena and Água Clara Intrusive Suites) and by minor bodies of

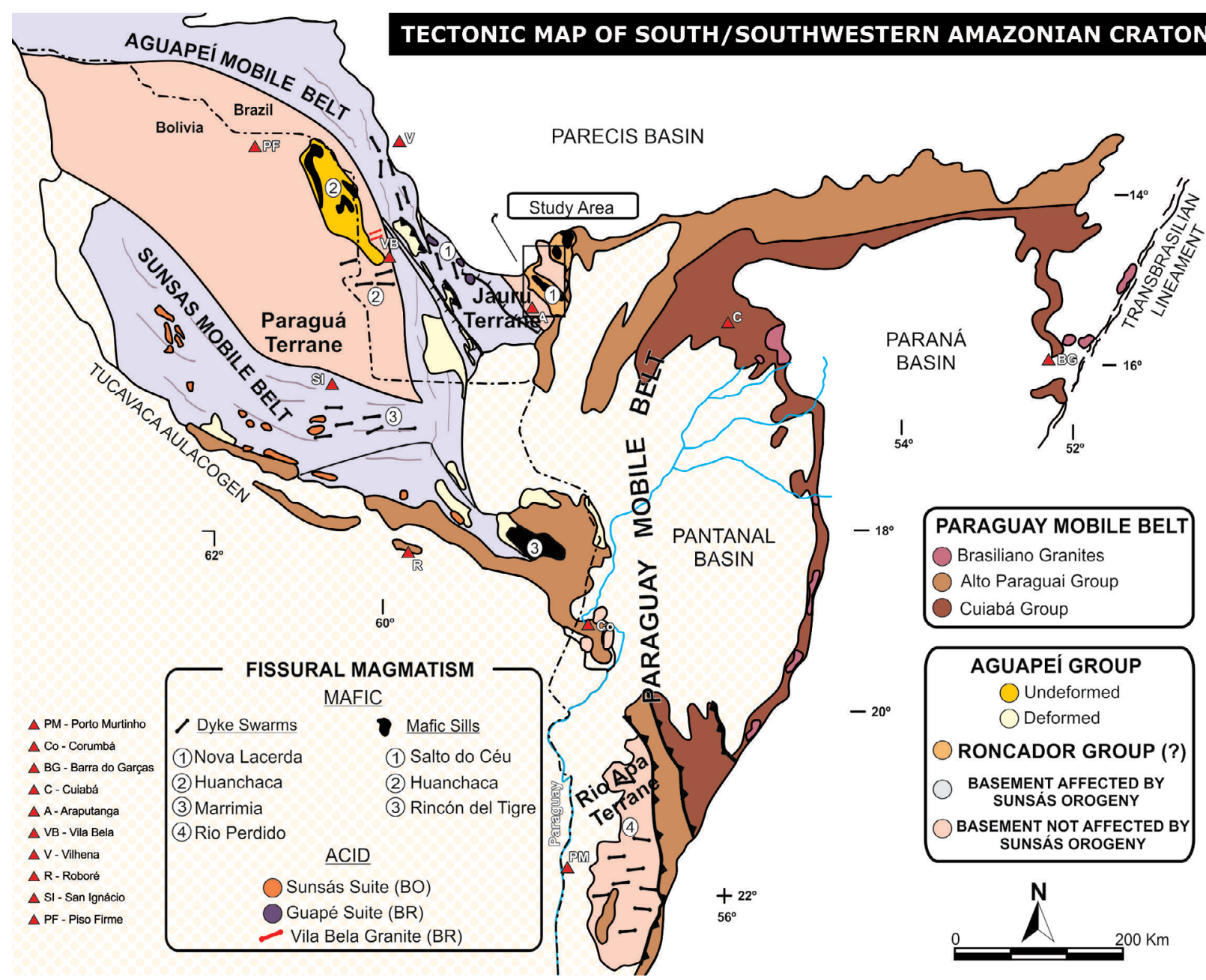

Figure 1. Tectonic Map of the South/Southwestern Amazonian Craton highlighting the fissural mafic magmatism (dykes of the intrusive suites Rio Perdido, Nova Lacerda and Huanchaca; and sills of the Salto do Céu and Huanchaca intrusive suites), and felsic magmatism (plutons of the Guapé Intrusive Suite and granitic dykes of the Vila Bela Granite). Extracted and modified from Ruiz et al. 2010b. 
the Intrusive Suite Pindaituba (1465-1425 Ma), with large compositional variation (Ruiz 2005).

Araújo et al. (2005) named as Salto do Céu Intrusive Suite the assemblage of intrusions occurring parallel to the bedding of pelites and psammites of the Vale da Promissão Formation (Aguapeí Group), and composed of mafic sills 1 to $5 \mathrm{~m}$ thick. Araújo-Ruiz et al. (2007) recognized two main plutonic series in the Rio Branco Intrusive Suite, one of basic nature with discontinuous distribution located in the intrusion borders, and another one of acid/intermediate nature that is composed of three petrographic facies. It was concluded that the occurrence of gabbroic rocks represent two separate magmatic events: the basic plutonic rocks (gabbros and diorites) belonging to the Rio Branco Intrusive Suite, and the shallow intrusions (diabases, microgabbros) belonging to the Salto do Céu Intrusive Suite.

Araújo (2008) obtained U-Pb (TIMS) ages of $1403 \pm 0.6 \mathrm{Ma}$ and $1382 \pm 49 \mathrm{Ma}$ for the intermediate to acid rocks, interpreted as the time of igneous crystallization for felsic magmas that gave rise to the Rio Branco Intrusive Suite.

The Rio Branco Intrusive Suite, as reported by Araújo et al. (2009) and Araújo \& Godoy (2011), comprises two main plutonic suites: the Rio Branco Basic Intrusive Suite that is composed of basic to intermediate rocks, and the Rio Branco Acid Intrusive Suite which is intermediate to acid in composition. Also, according to these authors, the gabbroic association comprises two temporally distinct magmatic events: the first one is composed of basic to intermediate plutonic rocks, such as microgabbros to diabases, monzogabbros, and quartz-monzonites to quartz-diorites that are grouped into the Rio Branco Basic Intrusive Suite; the other magmatic event include hypoabissal lithotypes, such as diabases and microgabbros, occurring as sills hosted by the Aguapeí Group, and grouped together under the name of Salto do Céu Basic Intrusive Suite.

Based on more detailed geological mapping, Sousa et al. (2017) assigned the term Rio Branco Intrusive Suite only to acid to intermediate rocks, thus assigning all the basaltic and gabbroic rocks to the Salto do Céu Intrusive Suite.

Teixeira et al. (2016) obtained U-Pb baddeleyite ages of $1439 \pm 4 \mathrm{Ma}$ for the Salto do Céu sills, and of $1387 \pm 17 \mathrm{Ma}$ for the Nova Lacerda mafic dyke swarms. These ages reflect a single magmatic event for these units associated with the evolution of the Columbia Supercontinent.

Mesoproterozoic sedimentary and metasedimentary rocks occurring in the southwest of Mato Grosso, and in Eastern Bolivia were first reported in the LASA report (1968). These rocks were latter named Aguapeí Unit by Figueiredo \& Olivatti (1974). Souza \& Hildred (1980) used the term Aguapeí Group in order to group the formations Fortuna, Vale da Promissão and Morro Cristalina, which was then described as a marine transgressive-regressive platform cover sequence.

According to Saes (1999), the Fortuna Formation is composed of sandstones and orthoquartzitic conglomerates. These rocks with widespread cross-bedding indicates deposition in braided fluvial systems in the areas of Huanchaca and Sao Vicente Hills which eventually prograded into a shallow-marine platform influenced by tidal currents, fan deltas and tempestites in the region of Pontes and Lacerda, and Rio Branco. The Vale da Promissão Formation represents a progradational wedge of marine sediments thickening towards the SE. In the regions of Rio Branco, and Pontes and Lacerda, this unit consists of pelitic rocks intercalated with sandstones that were deposited by storms on shallow marine platform. The Morro Cristalina Formation is chiefly composed of quartz-arenites, and rarely composed of conglomerates whose main characteristics are the high level of maturity and the exclusive continental character (fluvial and eolian) of its deposits.

Geraldes et al. (2014) obtained U-Pb (LA-ICP-MS) ages on detrital zircons for samples from the Aguapeí Group collected in three hills: Rio Branco, Ricardo Franco and Santa Bárbara. The results from the Rio Branco Hill, same region where the target rocks crop out, yield four main age peaks at 1544, 1655, 1812 and $2515 \mathrm{Ma}$. According to these authors, the first peak is likely related to the rocks of the Cachoeirinha orogeny, the second peak represents the rocks of the Lomas Manechis Complex (Bolivia) and, in their turn, the last two peaks may represent the older units not mapped yet.

Table 1 shows geochronological data available for the acid to intermediate rocks and basic rocks, respectively, from the Rio Branco and Salto do Céu suites.

\section{GEOLOGICAL AND PETROGRAPHIC CHARACTERIZATION}

The basic rocks crop out in the study area as sills and lava flows, blocks or as large low-lying outcrops along drainages. The main outcrops are exposed on the road joining the town of Salto do Céu to the Progresso Village, on the upper reaches of the Bracinho Stream in the municipality of Rio Branco, and on the slopes of the homonymous hill (Fig. 2).

Locally, typical magma mingling features can be observed in the Rio Branco Suite outcrops. These features consist of mafic microgranular enclaves within the felsic rocks (Figs. 3A and $3 \mathrm{~B}$ ). The mafic microgranular enclaves show alkali feldspar xenocrysts with reabsorption features and recurrent transitional and diffuse boundaries, and centimeter size hybridization zones in the contact with the felsic rock. 
Mafic microgranular enclaves are pointed by Barbarin and Didier (1992) and Barbarin (2005) as indicative of magma mingling processes. The hybridization zone, restricted to the enclaves margins, indicates the subordinated actuation of mixing processes, commonly observed in granitoid evolved by magma interaction, as suggested by Barbey et al. (2008).

Sills are 2 to $30 \mathrm{~m}$ thick, and show well-defined intrusive contacts with pelites of Vale da Promissão Formation (Fig. 3C) as well as tectonic contacts with the sandstones of Morro Cristalina Formation as a result of normal faulting. They are gently dipping between $10^{\circ}$ and $15^{\circ} \mathrm{WSW}$, and in some places their dip is $5^{\circ}$ toward both SW and ENE. The shape-rounded outcrops display typical spheroidal exfoliation.

Lava flows are about $6 \mathrm{~m}$ thick and show vertical internal structures as well as flow-top structures, typical of thin basaltic lava flows $(<10 \mathrm{~m})$ as highlighted by Aubele et al. (1988) and Cashman \& Kauahikaua (1997). Their internal structure is marked by zoning consisting of an upper vesicular portion $(-1.7 \mathrm{~m})$, and another intermediate portion without vesicular texture $(-4.0 \mathrm{~m})$; no vesicular lower portion was recognized as usual in the basaltic lava flows.
The abundance and size of vesicles increase toward the top (Figs. 4A and 4B). Flow folds (Figs. 4C and 4D) deformed during lava flow motion result in surfaces of pahoehoe flows observed at the top of flows (30 to $40 \mathrm{~cm}$ below the top). The deformation caused by lava flow motion also led to fragmentation of ropy lava in the upper crusts resulting in its brecciated aspect (Figs. $4 \mathrm{E}$ and $4 \mathrm{~F}$ ), in places showing rapakivi texture (Fig. $4 \mathrm{G}$ ) and formation of alkali feldspar phenocrysts partially resorbed (Fig. $4 \mathrm{H}$ ). Internal structures and flow-top aspects are characteristics similar to those pointed out by Chitwood (1994), Hon et al. (1994) and Self et al. (1998) for pahoehoe inflated flows deposited in subaerial settings. Vesicles are mostly filled with fibrous to fibro-radiated material consisting of zeolites chlorite, fluorite and opaque minerals.

Both sills and lava flows are mesocratic to melanocratic, greenish-gray to black in colour, and equigranular varying from very fine- to medium-grained.

The sills consist of diabases and massif gabbros that under the microscope display ophitic, subophitic, intergranular, and coronitic textures (Figs. 5A, 5B and 5C). They are essentially composed of plagioclase and pyroxene, having as accessory

Table 1. Geochronological and isotopic database for the acid to intermediate rocks (Rio Branco Suite) and basic rocks (Salto do Céu Suite).

\begin{tabular}{|c|c|c|c|c|c|c|c|}
\hline & \multirow{2}{*}{ References } & \multirow{2}{*}{$\begin{array}{c}\text { U-Pb } \\
\text { Age (Ma) }\end{array}$} & \multicolumn{2}{|c|}{$\mathbf{R b}-\mathrm{Sr}$} & \multicolumn{2}{|c|}{ Sm-Nd } & \multirow{2}{*}{$\begin{array}{c}\text { K-Ar } \\
\text { Age (Ma) }\end{array}$} \\
\hline & & & Age (Ma) & $\left({ }^{87} \mathrm{Sr} /{ }^{86} \mathrm{Sr}\right)_{0}$ & $\mathrm{~T}_{\mathrm{DM}}(\mathrm{Ga})$ & $\varepsilon \mathbf{N d}(\mathrm{t})$ & \\
\hline \multirow{6}{*}{ 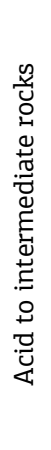 } & Barros et al. (1982) & - & $\begin{array}{c}\text { (WR) } \\
1130 \pm 72\end{array}$ & 0,708 & - & - & - \\
\hline & Ruiz (1992) & - & $\begin{array}{c}\text { (WR) } \\
1126 \pm 39\end{array}$ & 0,7165 & - & - & - \\
\hline & Geraldes et al. (2001) & (Z) $1427 \pm 10$ & - & - & 1,89 a 1,79 & $-0,2$ & - \\
\hline & Geraldes et al. (2004) & (Z) $1423 \pm 0,2$ & - & - & 1,89 a 1,81 & $-0,96 a+0,16$ & - \\
\hline & Araújo (2008) & $\begin{array}{l}\text { (Z) } 1423 \pm 06 \\
\text { (Z) } 1380 \pm 49\end{array}$ & - & - & 1,91 a 1,65 & $-1,78 a+1,24$ & - \\
\hline & Sousa et al. (2017) & - & - & - & 2,08 & $-3,39$ & - \\
\hline \multirow{7}{*}{ 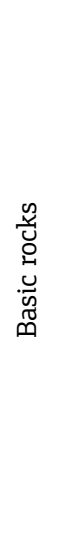 } & $\begin{array}{l}\text { Hama (1976) apud } \\
\text { Ruiz (2005) }\end{array}$ & - & - & - & - & - & (P) $1006 \pm 16$ \\
\hline & Barros et al. (1982) & - & - & - & - & - & $\begin{array}{l}\text { (WR) } 875 \pm 21 \\
\text { (P) } 878 \pm 10 \\
\text { (P) } 930 \pm 14 \\
\text { (P) } 960 \pm 21\end{array}$ \\
\hline & Leite et al. (1985) & - & - & - & - & - & (P) $1015 \pm 17$ \\
\hline & Geraldes et al. (2001) & (Z) $1471 \pm 08$ & - & - & 1,86 a 1,73 & $-2,3$ & - \\
\hline & Geraldes et al. (2004) & (Z) $1471 \pm 31$ & - & - & 1,86 a 1,73 & $-2,33 a+1,91$ & - \\
\hline & Araújo (2008) & (S) $808 \pm 620$ & - & - & 1,74 & $+2,61$ & - \\
\hline & Teixeira et al. (2016) & (B) $1439 \pm 4$ & - & - & - & - & - \\
\hline
\end{tabular}

Z: zircon; S: sphene; B: baddeleyite; WR: whole-rock; P: plagioclase. 
mineral assemblage opaque minerals, acicular apatite crystals, and subhedral brown sphene crystals. Alteration paragenesis is represented by amphibole, biotite, epidote/clinozoisite, sericite, calcite, clay minerals, and chlorite. Rare grains of alkali feldspar and quartz exhibiting graphic intergrowth are found as late-forming minerals.

The plagioclase, identified as labradorite occurs as subhedral to tabular euhedral crystals showing albite, pericline and Carlsbad twinning; in places, albite and Carlsbad twinning are combined. It is intensely argilized and saussuritized resulting in the formation of epidote/clinozoisite, sericite/muscovite and calcite.

The monoclinic pyroxene is identified as augite-titanoaugite and pigeonite being euhedral, prismatic, well-preserved, and mostly pink to dark pink in colour which indicates a Ti-rich composition, and exhibits sectorial twinning in places. Green amphibole occurs in reaction borders characterizing uralitization processes (Figs. 6A, 6B and 6C).

\section{GEOLOGICAL MAP OF SALTO DO CÉU AND RIO BRANCO REGION - MT}

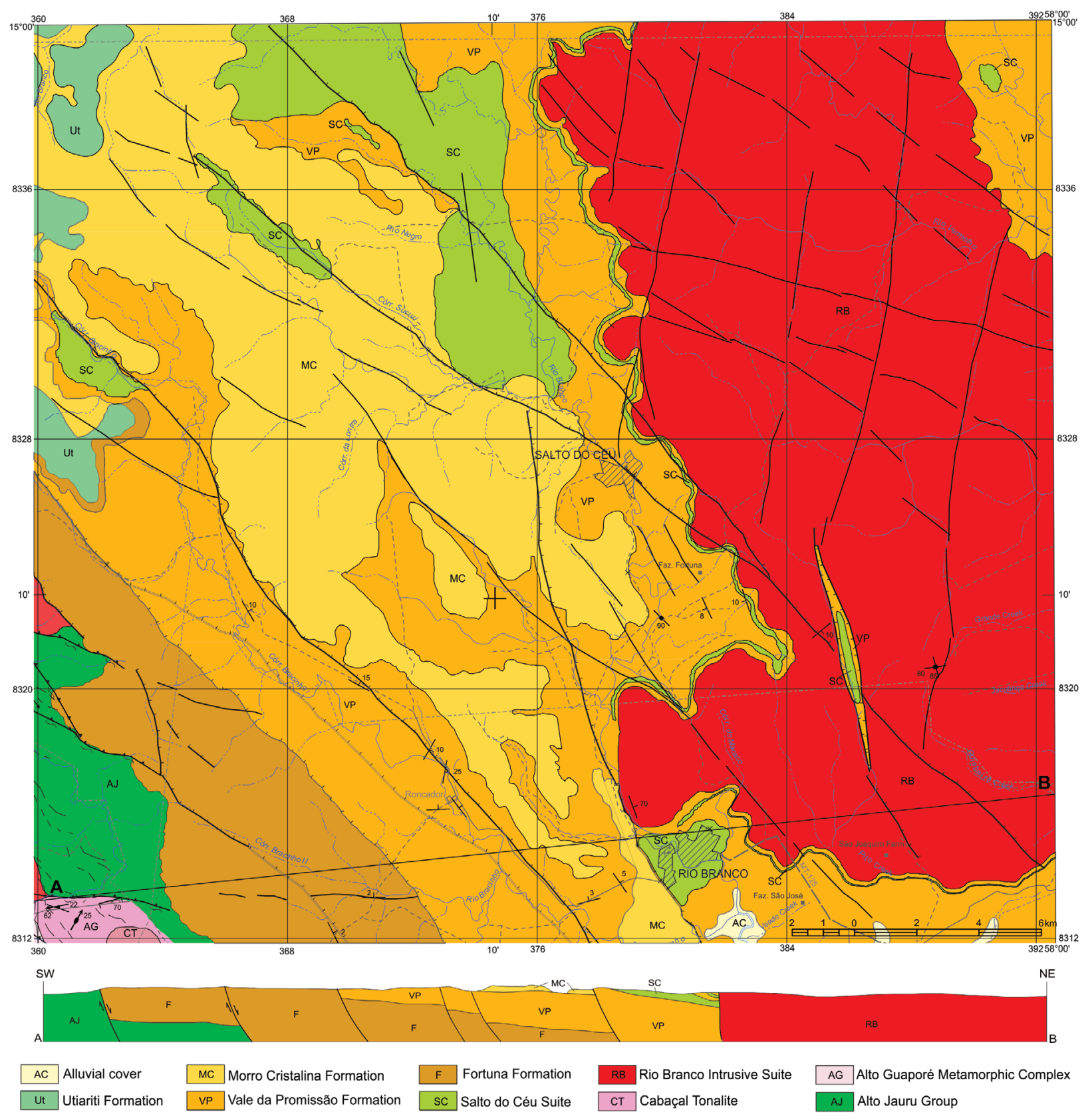

Source: modified from Sousa et al. 2017.

Figure 2. Location of the study area in the geological map of Salto do Céu and Rio Branco region, Mato Grosso. 
Occasionally, pyroxene shows complete pseudomorphism by amphibole, chlorite and biotite, but it may also occur as relict mineral.

The types of amphibole here observed are actinolite-tremolite and hornblende. Light green actinolite-tremolite occurs as acicular subhedral crystals, single crystals or fibrous aggregates that fills microvenules and microfractures following a fibrorradiated arrangement. They are mainly associated to the borders of pyroxene featuring coronitic texture, and may completely replace the pyroxene. Brown hornblende is observed as anhedral grains or pseudomorphs of pyroxene. It is usually altered to biotite and chlorite that may replace it completely.

Opaque minerals (Figs. 7A and 7B) are common in these rocks as well-developed, subhedral, skeletal and symplectite crystals, and may be partially replaced by biotite, chlorite, rutile and sphene.

Biotite is a common product from the alteration of amphibole, pyroxene or opaque minerals. These minerals are in places surrounded by a biotite fringe consisting of tiny fibrous crystals. Biotite seldom occur as well-developed blades with reddish brown to brownish pleochroism. Chlorite is observed in thin microscopic greenish blades displaying a fibrous to fibro-radiated habit. Chlorite also occurs associated with amphibole in pseudomorphs of pyroxene and opaques, or in a pervasive way as fracture filling in plagioclase.

Lava flows consist of basalts exhibiting the following textures: ophitic, subophitic, hyalophitic, porphyritic or amygdaloidal in pseudo-trachytic groundmass (Figs. 8A, 8B and $8 \mathrm{C})$; vitrophyric texture is also observed in some samples.

Their main components are plagioclase, pyroxene, and relict glass having as accessory and alteration paragenesis: amphibole, biotite, chlorite, opaque, rutile, sphalerite, apatite, sericite, epidote/clinozoisite, calcite and clay minerals.

The amygdales are round to ellipsoidal in shape, with diameter up to $3 \mathrm{~mm}$, filled by fibrous to fibro-radiated material (Figs. 9A, 9B, 9C, 9D, 9E and 9F) consisting of zeolites, chlorite, fluorite (Figs. 10A and 10B) and opaque
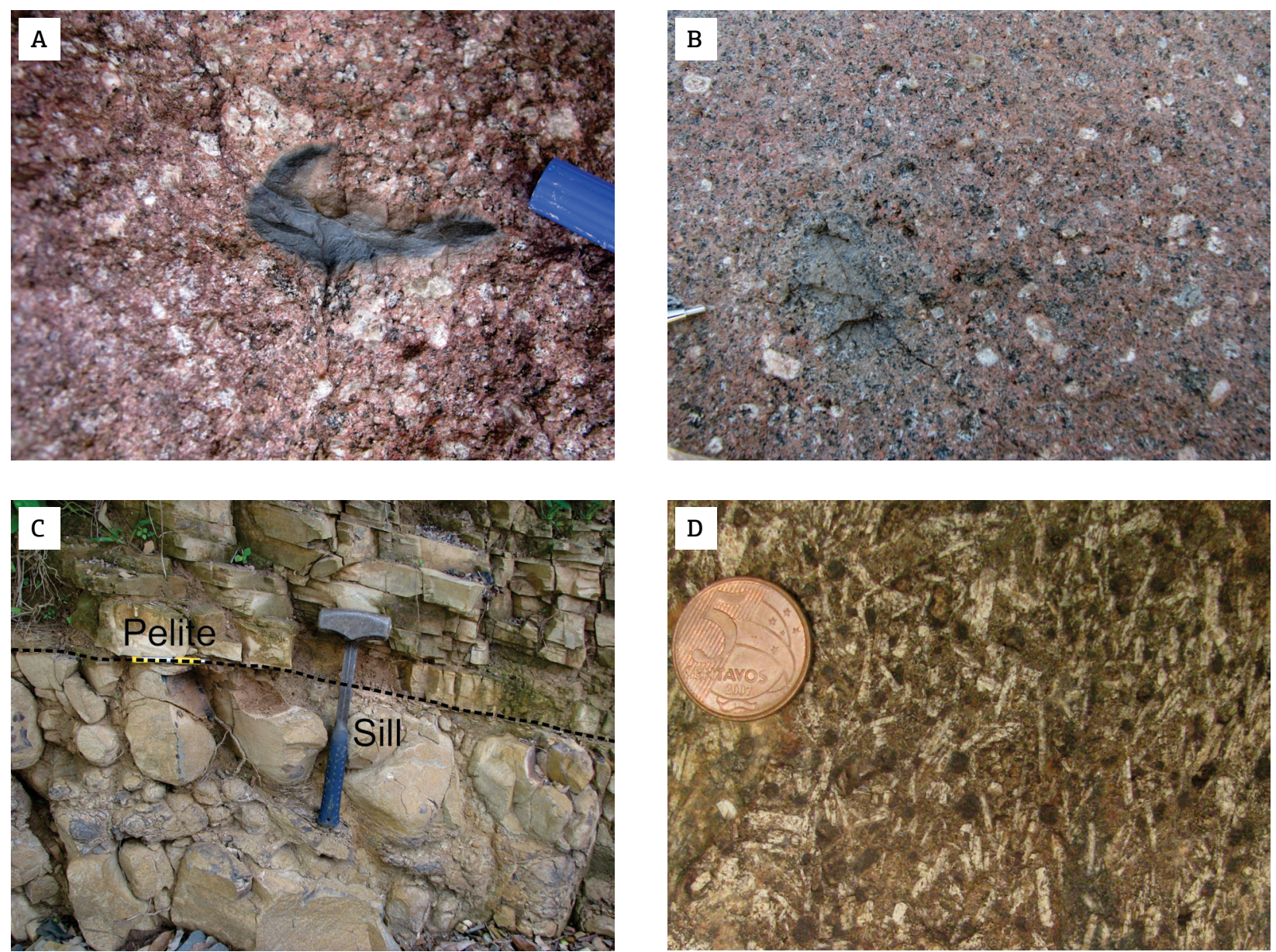

Figure 3. Field aspects of sills from Salto do Céu Suite: (A) mafic enclave likely from the Salto do Céu Suite enclosed in rocks of the Rio Branco Intrusive Suite; (B) hybridized areas resulting from interaction between felsic (Rio Branco Intrusive Suite) and mafic (Salto do Céu Suite) magmas; (C) concordant contact between sills of Salto do Céu Suite and laminated pelites of Vale da Promissao Formation; (D) macroscopic aspect of sills, with emphasis on subophitic texture marked by interstitial plagioclase laths between pyroxene crystals. 

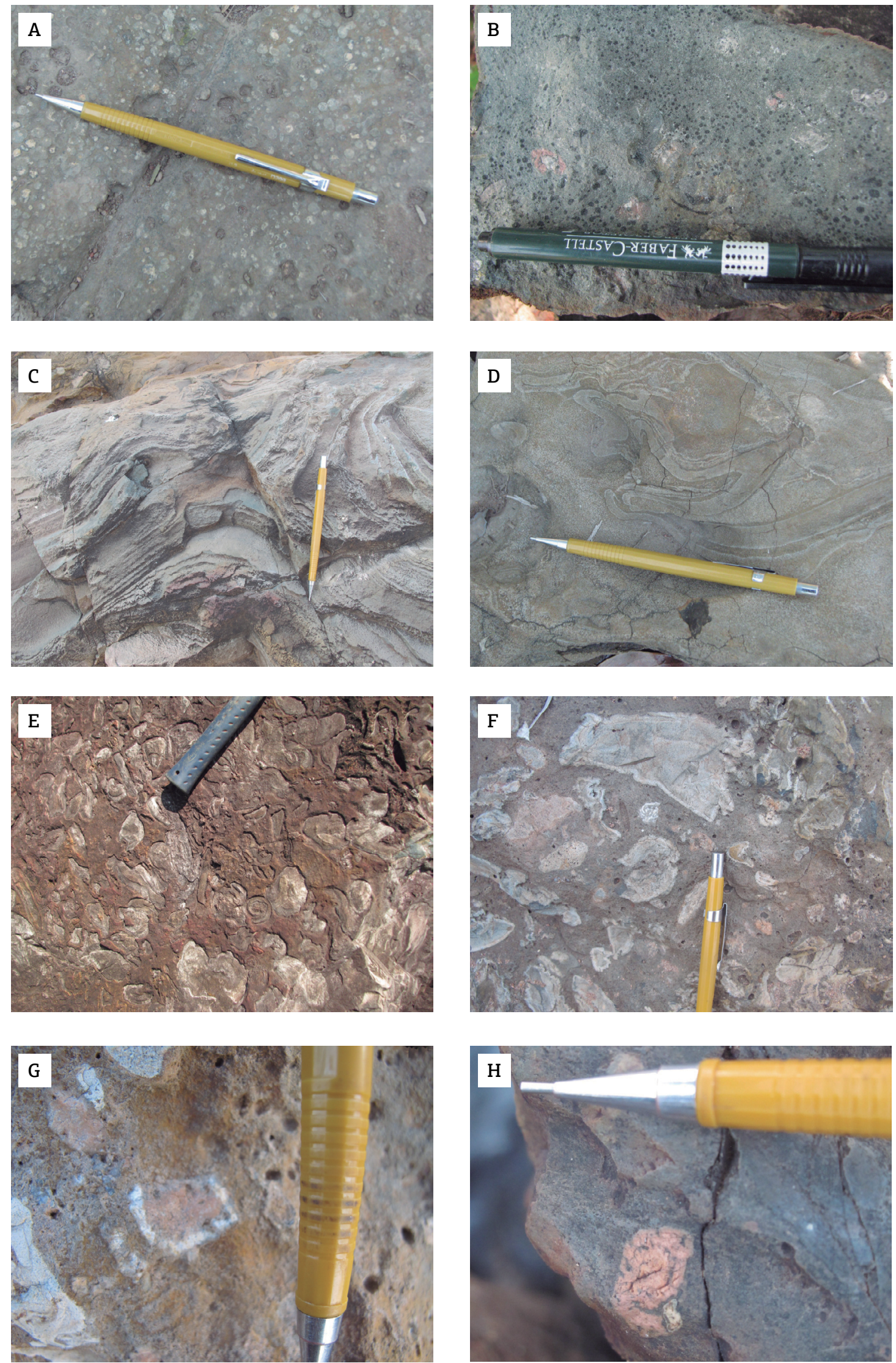

Figure 4. Field aspects of lava flows from Salto do Céu Suite: (A and B) large amount of round vesicles in the flow top; $(C$ and $D)$ flow folds; ( $E$ and $F$ ) brecciated aspect resulting from flow lava fragmentation as deformation occurs during its motion; $(\mathrm{G})$ and $\mathrm{H}$ ) alkali feldspar phenocryst displaying rapakivi texture and partially resorbed, respectively. 
minerals. They may present reaction rims composed of a red-coloured mixture of iron oxides/hydroxides, biotite and rutile.
Labradorite/andesine occurs as euhedral to subhedral tabular phenocrysts and submillimetre-sized laths displaying albite, pericline and Carlsbad twinning.
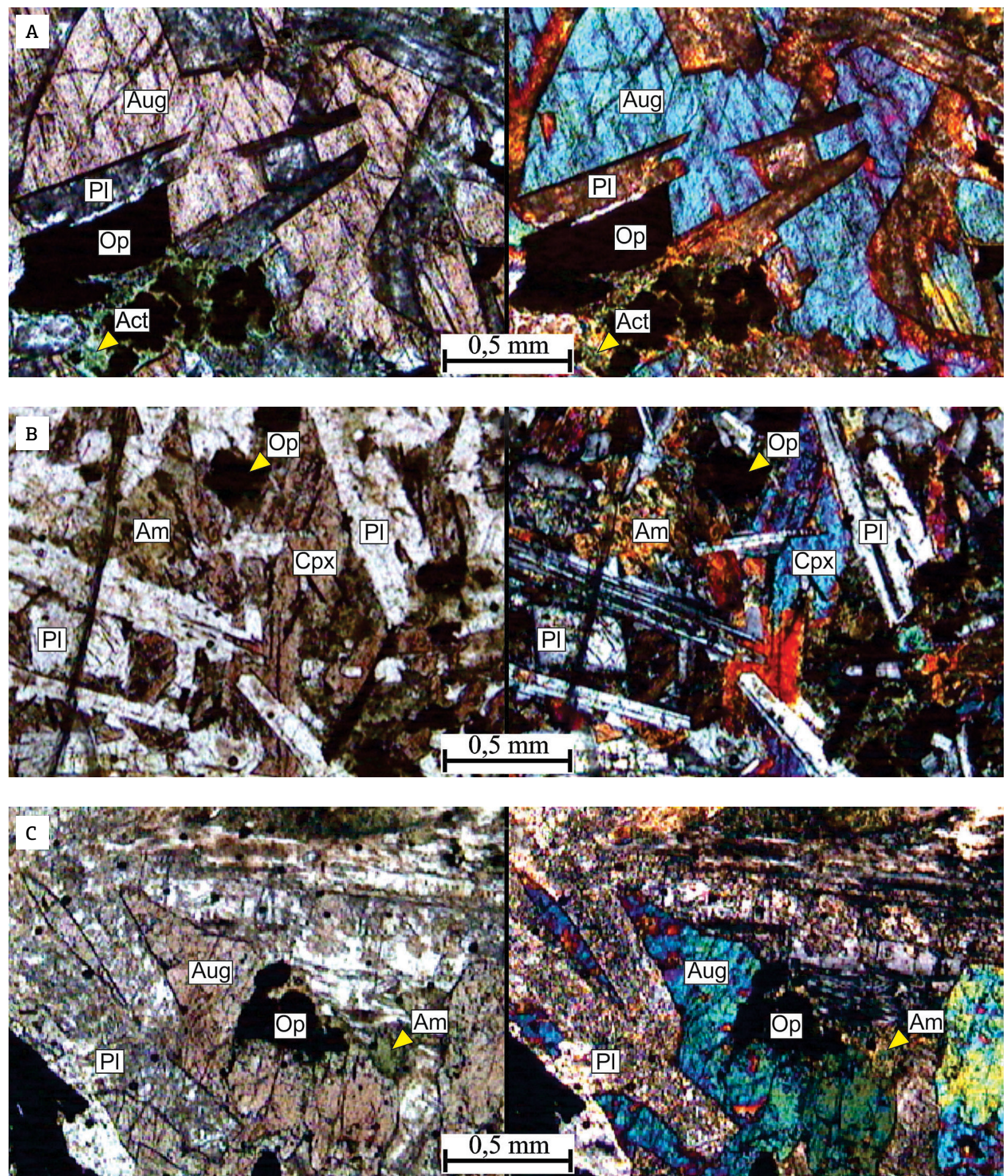

Figure 5. Photomicrographs of sills (gabbro) from Salto do Céu Suite displaying: (A) ophitic texture featured by pseudomorph augite (titanoaugite) crystal consisting of opaque minerals and actinolite, including intensely altered plagioclase laths; (B) tabular plagioclase between prisms and grains of pyroxene characterizing subophitic texture; (C) intergranular texture consisting of saussuritized tabular plagioclase crystals and partially uralitized interstitial pyroxene. Parallel polarizers to the left and crossed polarizers to the right. Abbreviations are as in Fettes \& Desmons (2008). 
Alteration processes such as argilization, sericitization, and mostly saussuritization are observed. Some crystals delineate a pseudotrachytic flow texture and may show normal, oscillatory and reverse zoning recognized by its higher degree of saussuritization in the more calcium-rich portions of plagioclase.
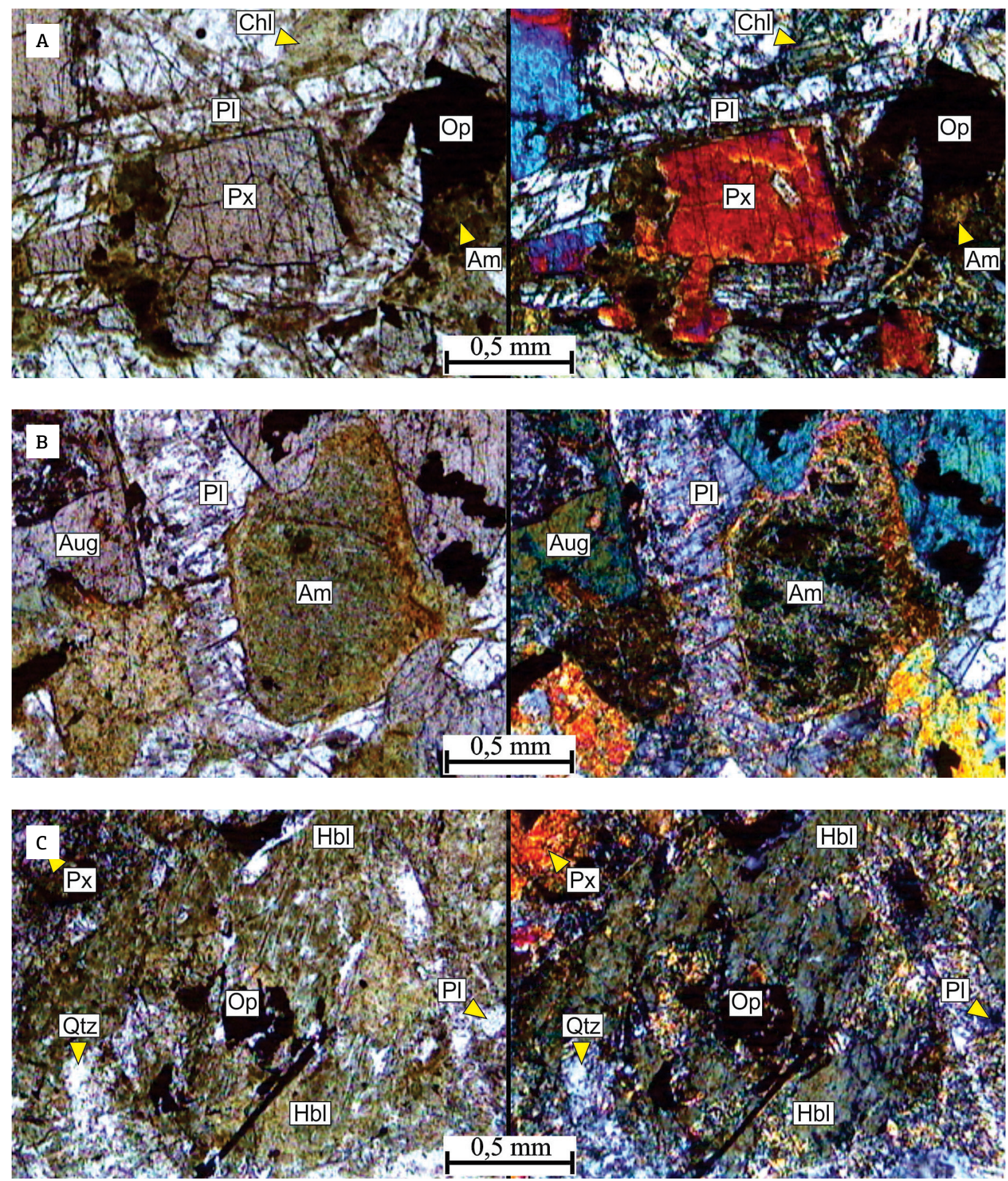

Figure 6. Photomicrographs of sills (gabbro) from the Salto do Céu Suite showing: (A) fractured plagioclase crystals, pyroxene and opaque minerals partially altered to amphibole, biotite and chlorite; (B) subophitic texture consisting of tabular plagioclase and augite crystals, some pseudomorphized by amphibole; (C) pseudomorph of amphibole (hornblende) after pyroxene associated with plagioclase, quartz and opaques. Parallel polarizers to the left and crossed polarizers to the right. Abbreviations are as in Fettes \& Desmons (2008). 
Clinopyroxene is identified as augite and pigeonite, white to pink in colour, in places exhibiting zoning and twinning, partially to completely uralitized or pseudomorphized by a mixture of amphibole, chlorite and biotite; some lithotypes contain orthopyroxene recognized as colourless to beige enstatite, partially altered to tremolite-actinolite and chlorite.

The amphibole types are products of pyroxene transformation occurring as hornblende prismatic crystals and grains, dark-green to brown in colour, and show drop-like quartz texture as well as acicular, fibrous and fibro-radiated, and white to greenish in colour tremolite-actinolite is seen. Both of them alters to biotite, chlorite and opaques.

Opaque minerals occur mostly as primary minerals or result from alteration of mafic minerals. They are more developed crystals showing dendritic habit and symplectitic texture, in places partially altered to biotite, chlorite, rutile, and sphene. Biotite occurs as tiny brown to brownish blades, sparsely distributed in the rock or in association with amphibole. Rare biotite crystals are found well-preserved and often result from the alteration of opaque minerals.

Reaction border consisting of calcite in very fine-grained fluidal groundmass (Fig. 10C), and euhedral sphalerite phenocrysts displaying magmatic corrosion (Figs. 10D and 10E).

\section{LITHOCHEMICAL CARACTERIZATION}

The lithochemical study of sills and lava flows from SCS was carried out on fourteen samples; also, sills and lava flows were studied together due to their chemical affinity. These samples were previously crushed and pulverized in the Sample Preparation Laboratory of the Geosciences College, Federal University of Mato Grosso, and forwarded to the Acme Analytical Laboratories (Vancouver, Canada) in order to measure major and minor elements, using ICP-ES, and trace-elements including rare earth elements using, ICP-MS.
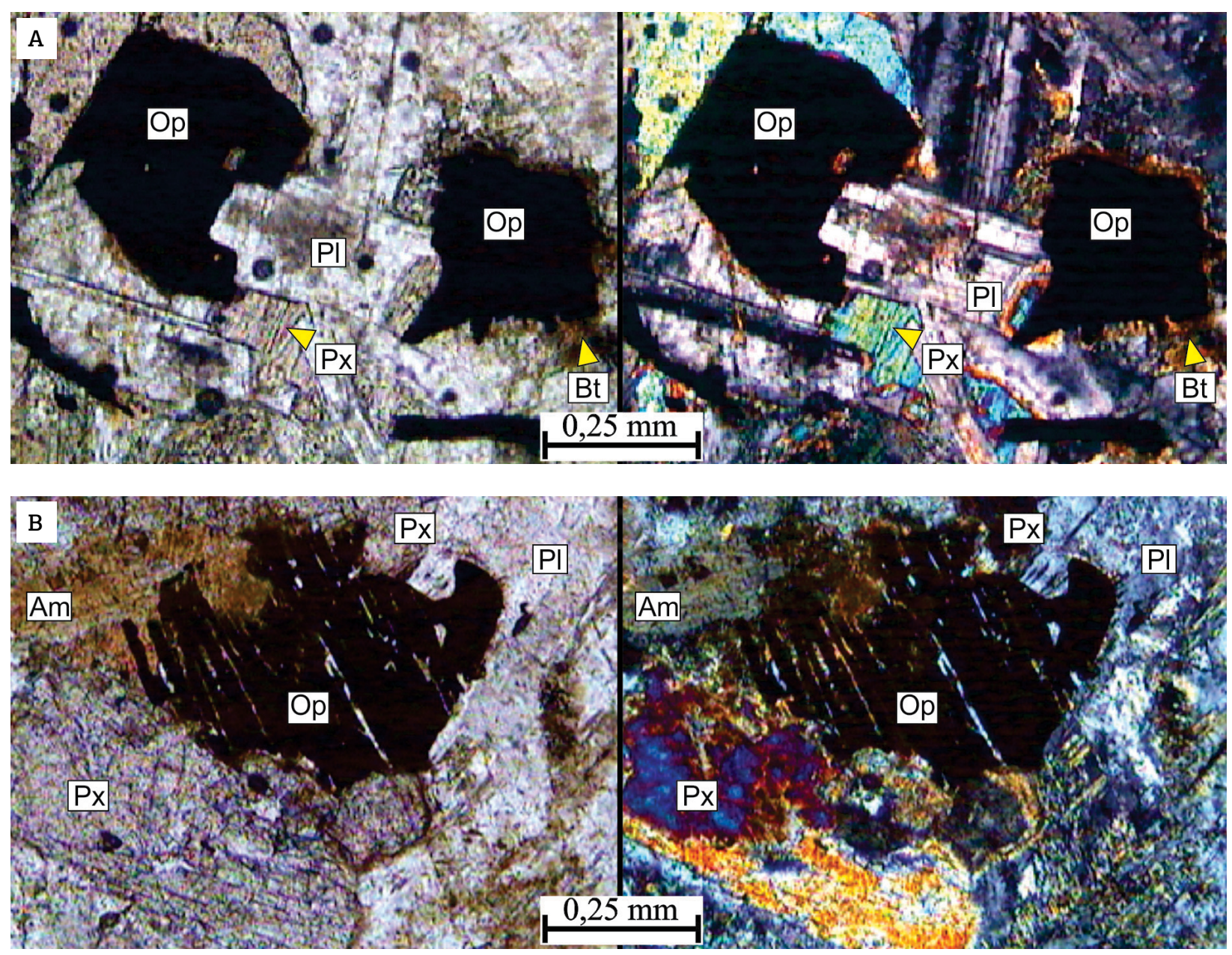

Figure 7. Photomicrographs of sills (diabase) from Salto do Céu Suite illustrating: (A) detail of opaque minerals with biotite corona and plagioclase showing normal zoning; (B) opaque mineral with symplectite texture associated with pyroxene, amphibole and plagioclase. Parallel polarizers to the left and crossed polarizers to the right. Abbreviations are as in Fettes \& Desmons (2008). 
Analytical data are shown on Table 2. Data processing was performed using GCDkit software (version 3.0, Geochemical Data Toolkit for Windows; Janoušek et al. 2006).
$\mathrm{MgO}$ contents vary between 3.75 and $6.86 \%$, and $\mathrm{SiO}_{2}$ contents vary between 44.03 and $49.32 \%$. Calculated mg\# values $\left[\mathrm{Mg} /\left(\mathrm{Mg}+\mathrm{Fe}^{+2}\right)\right]$ vary from 0.30 to 0.51 taking into
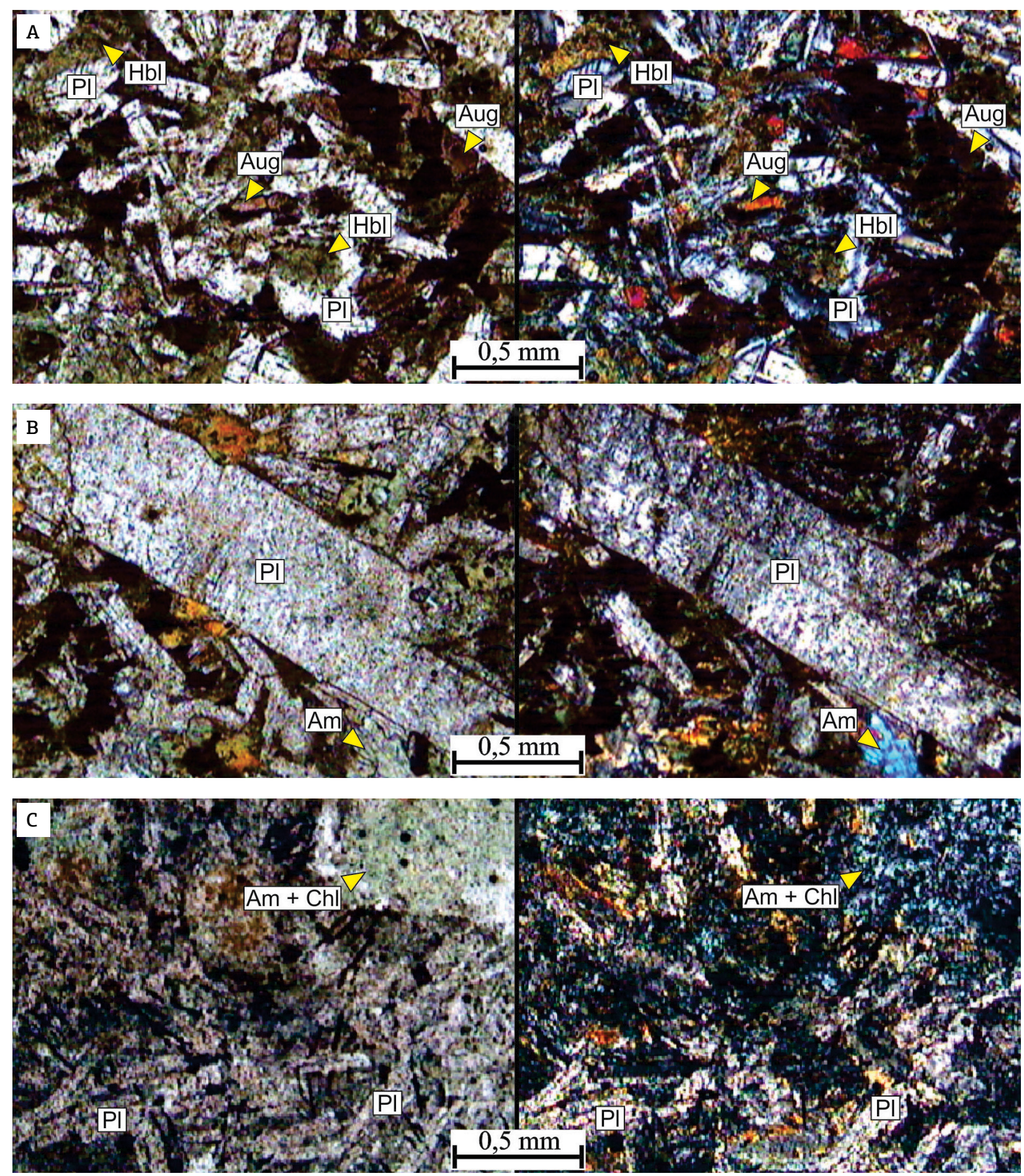

Figure 8. Photomicrographs of lava flows (basalt) from Salto do Céu Suite displaying: (A) ophitic to intergranular texture featured by plagioclase laths and dark-pink titanoaugite with partial to complete replacement by green-coloured hornblende; (B) porphyritic texture formed by tabular plagioclase enclosed into a subophitic to intergranular groundmass; (C) fluidal groundmass showing pseudo-trachytic texture delineated by the arrangement of deformed plagioclase laths intercalated with mafic minerals, and amphibole pseudomorphs of original pyroxene. Parallel polarizers to the left and crossed polarizers to the right. Abbreviations are as in Fettes \& Desmons (2008). 

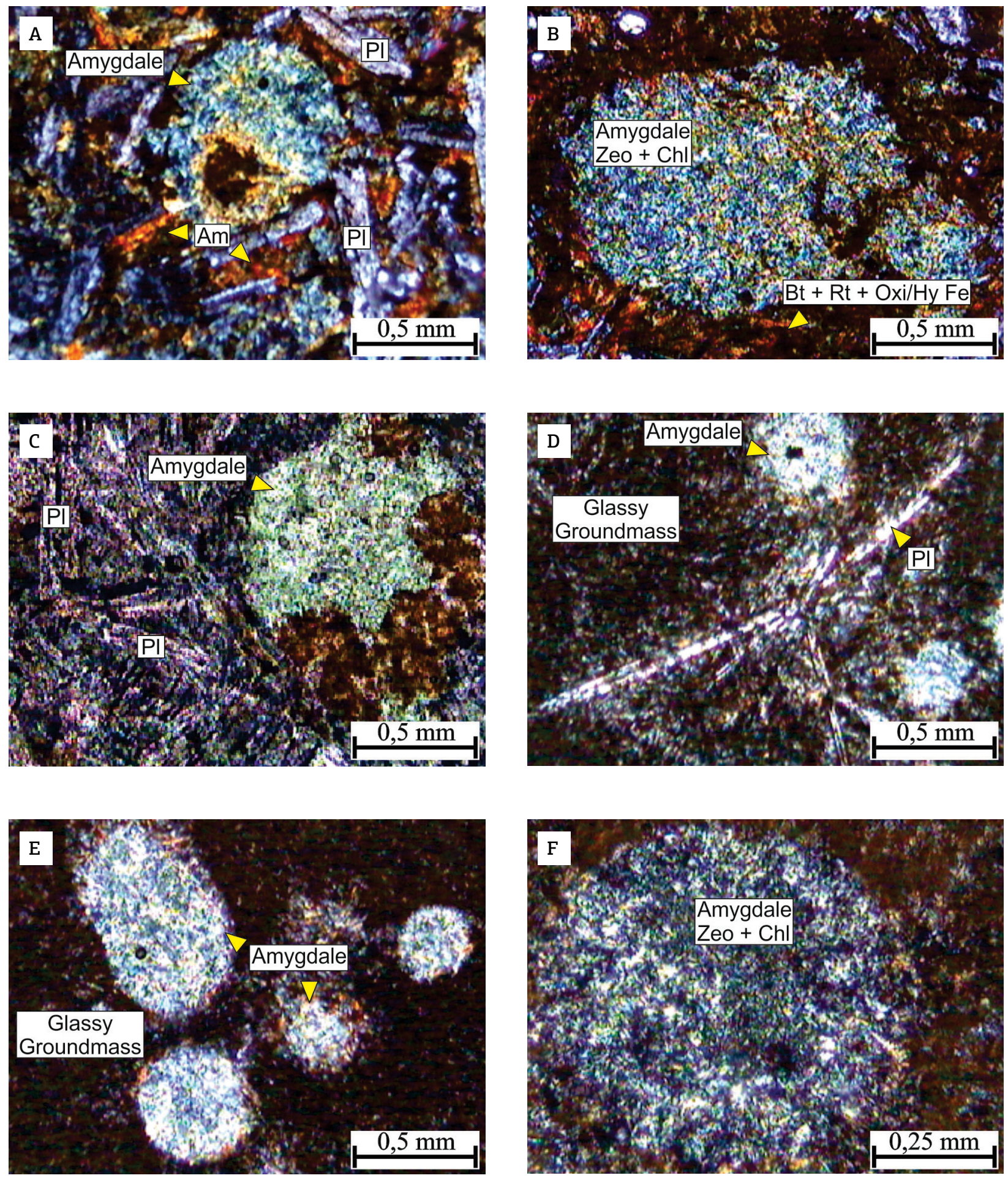

Figure 9. Photomicrographs of lava flows (basalt) from Salto do Céu Suite showing: (A) amygdale enclosed in subophitic groundmass with plagioclase laths and amphibole; (B) amygdale filled with zeolite and chlorite surrounded by a halo consisting of a mixture of biotite, rutile, and iron oxides/hydroxides; (C) amygdale filled with zeolite, chlorite, biotite, and iron oxides/hydroxides in fluidal groundmass; (D) vitrophyric texture formed by elongate laths of plagioclase phenocrysts and amygdales enclosed in glassy groundmass; (E) round and ellipsoidal amygdales in glassy groundmass; (F) Detail of rounded amygdale filled with zeolite and chlorite. Parallel polarizers in (C) and crossed polarizers in (A), (B), (D), (E) and (F). Abbreviations are as in Fettes \& Desmons (2008). 

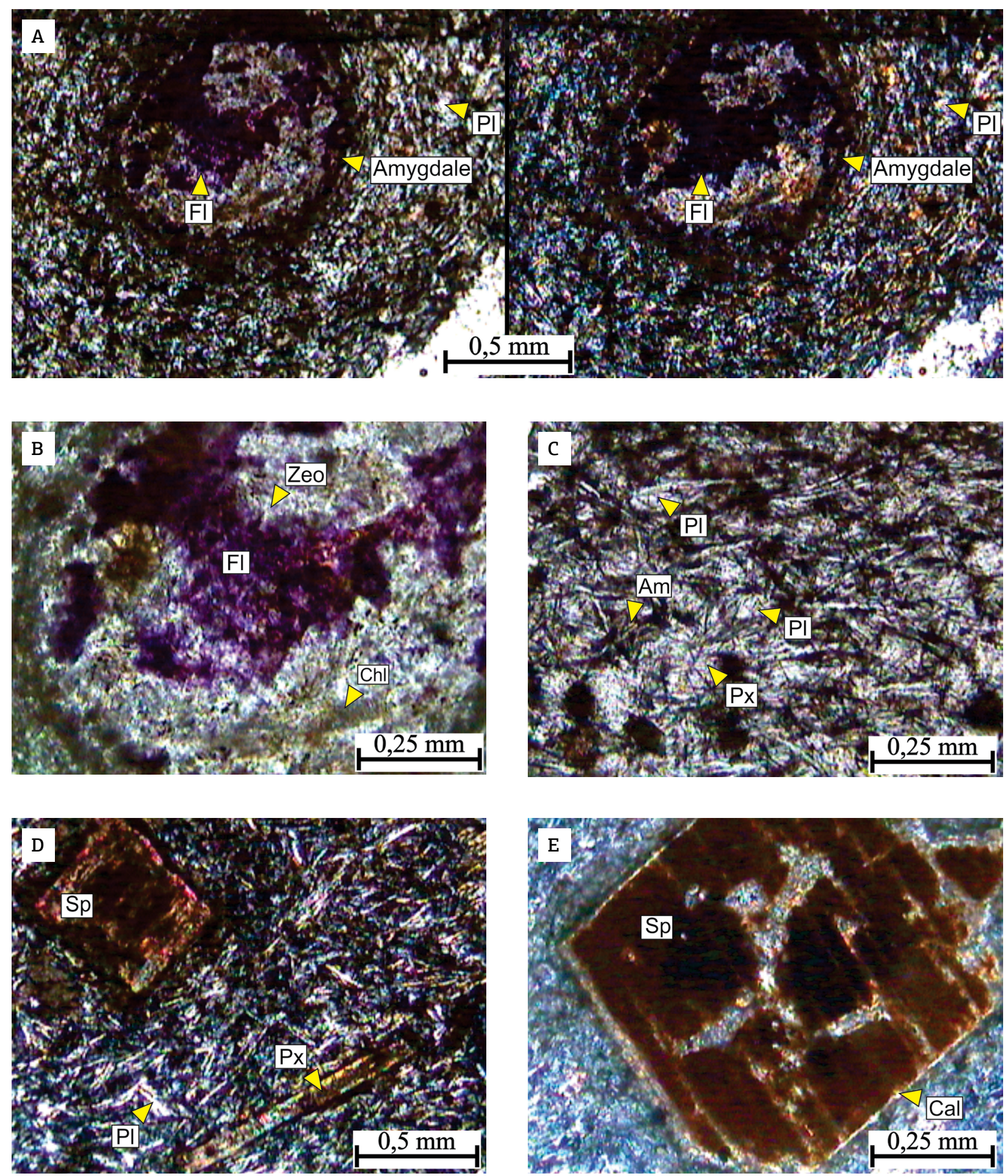

Figure 10. Photomicrographs of lava flows (basalt) from Salto do Céu Suite showing: (A) fine-grained groundmass with pseudo-trachytic texture marked by alignment of plagioclase laths and mafic minerals, and amygdale filled with secondary phases, such as fluorite, opaques, chlorite and zeolite; (B) details of previous image highlighting the purple colour of fluorite; (C) detail of groundmass composed of plagioclase laths, pyroxene grains and amphibole; (D) sphalerite and pyroxene phenocrysts in a trachytoid groundmass consisting of submillimetre-sized laths of plagioclase and mafic minerals; (E) detail of euhedral sphalerite crystal with magmatic corrosion and reaction rim of calcite. Parallel polarizers to the left and crossed polarizers to the right in (A), parallel in (B) and (C), and crossed polarizers in (D) and (E). 
Table 2. Lithochemical data of rocks from Salto do Céu Suite [major elements (\% weight), trace-elements (ppm)].

\begin{tabular}{|c|c|c|c|c|c|c|c|c|c|c|c|c|c|c|}
\hline & $\begin{array}{c}\text { \#RB } \\
533 A\end{array}$ & $\begin{array}{c}\text { \#RB } \\
\text { 42D2 }\end{array}$ & $\begin{array}{l}\text { \#RB } \\
22 B\end{array}$ & $\begin{array}{c}\text { \#RB } \\
22 \mathrm{C} 2\end{array}$ & $\begin{array}{l}\text { \#RB } \\
317\end{array}$ & $\begin{array}{l}\text { \#RB } \\
46 B\end{array}$ & $\begin{array}{l}\text { \#RB } \\
344\end{array}$ & $\begin{array}{l}\text { \#RB } \\
532\end{array}$ & $\begin{array}{l}\text { \#RB } \\
531\end{array}$ & $\begin{array}{l}\text { \#RB } \\
320\end{array}$ & $\begin{array}{c}\text { \#RB } \\
317 \mathrm{~A}\end{array}$ & $\begin{array}{c}{ }^{*} \mathrm{PG} \\
1205\end{array}$ & $\begin{array}{c}{ }^{*} \mathrm{PG} \\
1206\end{array}$ & $\begin{array}{c}{ }^{*} \mathrm{PG} \\
1203\end{array}$ \\
\hline $\mathrm{SiO}_{2}$ & 44.03 & 45.06 & 45.09 & 45.22 & 45.56 & 45.80 & 45.86 & 46.11 & 46.90 & 47.25 & 48.9 & 49.02 & 49.15 & 49.32 \\
\hline $\mathrm{TiO}_{2}$ & 2.23 & 3.48 & 2.03 & 2.74 & 2.15 & 2.59 & 2.65 & 2.88 & 4.38 & 3.92 & 3.67 & 3.65 & 3.25 & 3.30 \\
\hline $\mathrm{Al}_{2} \mathrm{O}_{3}$ & 15.76 & 14.78 & 16.53 & 14.45 & 15.83 & 16.10 & 16.23 & 16.09 & 11.73 & 12.41 & 13.04 & 13.68 & 13.90 & 13.63 \\
\hline $\mathrm{Fe}_{2} \mathrm{O}_{3 \mathrm{~T}}$ & 14.70 & 15.10 & 13.05 & 15.56 & 13.61 & 13.96 & 14.40 & 14.03 & 17.60 & 17.36 & 16.19 & 14.94 & 14.85 & 14.67 \\
\hline $\mathrm{MnO}$ & 0.19 & 0.19 & 0.16 & 0.20 & 0.17 & 0.19 & 0.19 & 0.19 & 0.23 & 0.22 & 0.15 & 0.23 & 0.21 & 0.22 \\
\hline $\mathrm{MgO}$ & 6.80 & 5.14 & 6.86 & 5.77 & 6.66 & 6.01 & 5.67 & 5.11 & 4.31 & 3.75 & 3.97 & 3.92 & 4.56 & 4.66 \\
\hline $\mathrm{CaO}$ & 8.57 & 8.88 & 7.98 & 8.52 & 8.5 & 8.65 & 8.93 & 8.48 & 8.98 & 8.25 & 5.81 & 6.22 & 5.05 & 6.89 \\
\hline $\mathrm{Na}_{2} \mathrm{O}$ & 2.58 & 2.9 & 2.98 & 3.41 & 2.75 & 2.77 & 2.82 & 2.95 & 2.64 & 2.93 & 3.54 & 3.28 & 3.72 & 2.69 \\
\hline $\mathrm{K}_{2} \mathrm{O}$ & 1.06 & 0.45 & 1.06 & 0.55 & 0.78 & 0.65 & 0.39 & 0.83 & 1.38 & 1.69 & 0.40 & 1.74 & 1.34 & 1.19 \\
\hline $\mathrm{P}_{2} \mathrm{O}_{5}$ & 0.35 & 0.66 & 0.34 & 0.45 & 0.38 & 0.49 & 0.49 & 0.54 & 0.59 & 0.67 & 0.70 & 0.61 & 0.58 & 0.57 \\
\hline LOI & 3.4 & 3 & 3.6 & 2.8 & 3.3 & 2.5 & 2.1 & 2.5 & 1 & 1.3 & 3.3 & 2.4 & 3.0 & 2.5 \\
\hline Sum & 99.67 & 99.64 & 99.68 & 99.67 & 99.69 & 99.71 & 99.73 & 99.71 & 99.74 & 99.75 & 99.67 & 99.69 & 99.61 & 99.64 \\
\hline $\mathrm{Ba}$ & 437 & 312 & 455 & 326 & 562 & 390 & 350 & 491 & 516 & 631 & 562 & 826 & 1183 & 772 \\
\hline $\mathrm{Rb}$ & 27.5 & 12.1 & 31.3 & 12.2 & 22.3 & 19.3 & 9.1 & 17.3 & 32.7 & 39.8 & 22.3 & 53.9 & 40.0 & 32.4 \\
\hline $\mathrm{Sr}$ & 537.7 & 338.4 & 515.4 & 499.8 & 611.1 & 352.8 & 345.2 & 345.7 & 291.6 & 293.7 & 611.1 & 295.1 & 333.2 & 293.3 \\
\hline $\mathrm{Zr}$ & 150.3 & 244.1 & 134.1 & 173.1 & 153.1 & 205.6 & 205.5 & 215.8 & 255 & 313 & 329.1 & 283.2 & 261.3 & 251.1 \\
\hline $\mathrm{Nb}$ & 12.6 & 21.4 & 11.3 & 15.5 & 12.9 & 13.5 & 13.9 & 14.8 & 19.9 & 22.2 & 12.9 & 19.5 & 18.2 & 16.7 \\
\hline $\mathrm{Zn}$ & 70 & 88 & 58 & 81 & 84 & 89 & 91 & 91 & 97 & 119 & 196 & 86 & 107 & 72 \\
\hline $\mathrm{La}$ & 17.5 & 30.3 & 16.5 & 21.6 & 18.6 & 18.6 & 20.2 & 20.4 & 28.7 & 35.6 & 42.7 & 34.2 & 35.0 & 29.4 \\
\hline $\mathrm{Ce}$ & 40.7 & 69.2 & 38.2 & 51.8 & 43.5 & 44.2 & 46.5 & 50 & 68.3 & 79.9 & 98.7 & 75.0 & 74.8 & 65.3 \\
\hline $\operatorname{Pr}$ & 5.71 & 9.55 & 5.35 & 7.18 & 6.16 & 6.34 & 6.66 & 6.82 & 9.51 & 11 & 13.12 & 10.19 & 9.91 & 8.90 \\
\hline $\mathrm{Nd}$ & 26.5 & 41.7 & 24.3 & 32 & 26.1 & 27.8 & 29.1 & 30.7 & 43.6 & 50.1 & 56.9 & 42.8 & 42.2 & 39.3 \\
\hline Sm & 5.56 & 8.92 & 5.02 & 6.8 & 5.6 & 6.2 & 6.61 & 6.9 & 9.62 & 10.76 & 12.15 & 9.27 & 9.32 & 8.73 \\
\hline $\mathrm{Eu}$ & 1.94 & 2.71 & 1.81 & 2.28 & 2.01 & 2.15 & 2.22 & 2.26 & 2.74 & 3.08 & 3.31 & 2.71 & 2.63 & 2.39 \\
\hline Gd & 5.84 & 9.29 & 5.14 & 6.87 & 5.71 & 6.53 & 7.04 & 7.35 & 10.09 & 11.45 & 12.93 & 10.06 & 9.63 & 8.94 \\
\hline $\mathrm{Tb}$ & 0.91 & 1.49 & 0.82 & 1.11 & 0.92 & 1.14 & 1.17 & 1.19 & 1.61 & 1.71 & 2.07 & 1.61 & 1.51 & 1.40 \\
\hline Dy & 5.06 & 8.05 & 4.53 & 6.14 & 5.12 & 6.41 & 6.35 & 6.79 & 9.53 & 10.25 & 11.75 & 9.46 & 9.46 & 8.26 \\
\hline Ho & 1 & 1.62 & 0.89 & 1.19 & 1.01 & 1.25 & 1.31 & 1.31 & 1.82 & 2.02 & 2.31 & 1.67 & 1.62 & 1.61 \\
\hline $\mathrm{Er}$ & 2.79 & 4.39 & 2.38 & 3.35 & 2.83 & 3.61 & 3.75 & 3.7 & 4.94 & 5.39 & 6.58 & 4.59 & 4.72 & 4.56 \\
\hline $\mathrm{Tm}$ & 0.4 & 0.65 & 0.36 & 0.49 & 0.39 & 0.52 & 0.54 & 0.55 & 0.76 & 0.81 & 0.94 & 0.74 & 0.65 & 0.65 \\
\hline $\mathrm{Yb}$ & 2.37 & 4.15 & 2.3 & 3.04 & 2.5 & 3.09 & 3.41 & 3.46 & 4.44 & 5.02 & 5.92 & 4.58 & 4.08 & 3.83 \\
\hline $\mathrm{Lu}$ & 0.36 & 0.57 & 0.31 & 0.43 & 0.36 & 0.46 & 0.5 & 0.52 & 0.65 & 0.73 & 0.84 & 0.71 & 0.64 & 0.63 \\
\hline $\mathrm{Y}$ & 33.4 & 43 & 23.3 & 32.9 & 27.1 & 33.5 & 35.6 & 36.5 & 49.8 & 52.5 & 66 & 46.7 & 43.4 & 42.0 \\
\hline $\mathrm{Ga}$ & 19.5 & 24.9 & 20.2 & 21.7 & 22.1 & 23.3 & 22.3 & 21.6 & 23.1 & 24.4 & 22.1 & 21.2 & 21.2 & 20.0 \\
\hline $\mathrm{mg} \#$ & 0.48 & 0.40 & 0.51 & 0.42 & 0.49 & 0.46 & 0.44 & 0.42 & 0.33 & 0.30 & 0.33 & 0.34 & 0.38 & 0.39 \\
\hline
\end{tabular}

\#: Sills; *lava flows. 
account $\mathrm{Fe}_{2} \mathrm{O}_{3} / \mathrm{FeO}$ equals 0.15 . These values suggest an evolved basaltic magma source for these rocks, once higher values between 0.74 and 0.80 refers to primitive magma (Jaques \& Green 1979, 1980, Takahari \& Kushiro 1983).

Major and trace-elements variation diagrams using $\mathrm{MgO}$ as differentiation index (Fenner's diagrams; Figs. 11 and 12) define relative linear trends. A negative relationship is observed in the major-elements diagrams between $\mathrm{MgO}$ and contents of $\mathrm{SiO}_{2}, \mathrm{TiO}_{2}, \mathrm{P}_{2} \mathrm{O}_{5}, \mathrm{Fe}_{2} \mathrm{O}_{3}$ and $\mathrm{MnO}$, while $\mathrm{CaO}$ and $\mathrm{Na}_{2} \mathrm{O}$ are randomly distributed, which suggests they were largely mobilized during post-magmatic events. $\mathrm{K}_{2} \mathrm{O}$ yields a divergent pattern in which its content decreases and then increases again as the $\mathrm{MgO}$ content decreases.
Trace-elements show that concentrations of $\mathrm{Ba}, \mathrm{Nb}, \mathrm{Zr}$, La, $\mathrm{Ce}$ and $\mathrm{Y}$ decrease as $\mathrm{MgO}$ content increases.

The rocks from Salto do Céu Suite have tholeiitic affinity with typical $\mathrm{FeO}_{\mathrm{t}}$ enrichment relative to $\mathrm{MgO}$ taking into account nearly constant alkali values, as seen in the AFM diagram (Irvine \& Baragar 1971; Fig. 13A), and are classified as sub-alkaline basalts and iron-rich tholeiitic basalts following the classification of Winchester \& Floyd (1977; Fig. 13B) and Jensen (1976; Fig. 13C), respectively.

In order to unravel their tectonic settings, diagrams $\mathrm{Zr} / \mathrm{Y}$ versus $\mathrm{Zr}$ (Pearce \& Norry 1979; Fig. 13D), $\mathrm{Zr}-\mathrm{Nb}-\mathrm{Y}$ (Meschede 1986; Fig. 13E) and $\mathrm{MgO}-\mathrm{FeO}_{\mathrm{t}}-\mathrm{Al}_{2} \mathrm{O}_{3}$ (Pearce et al. 1977; Fig. 13F) were elaborated in which the rocks
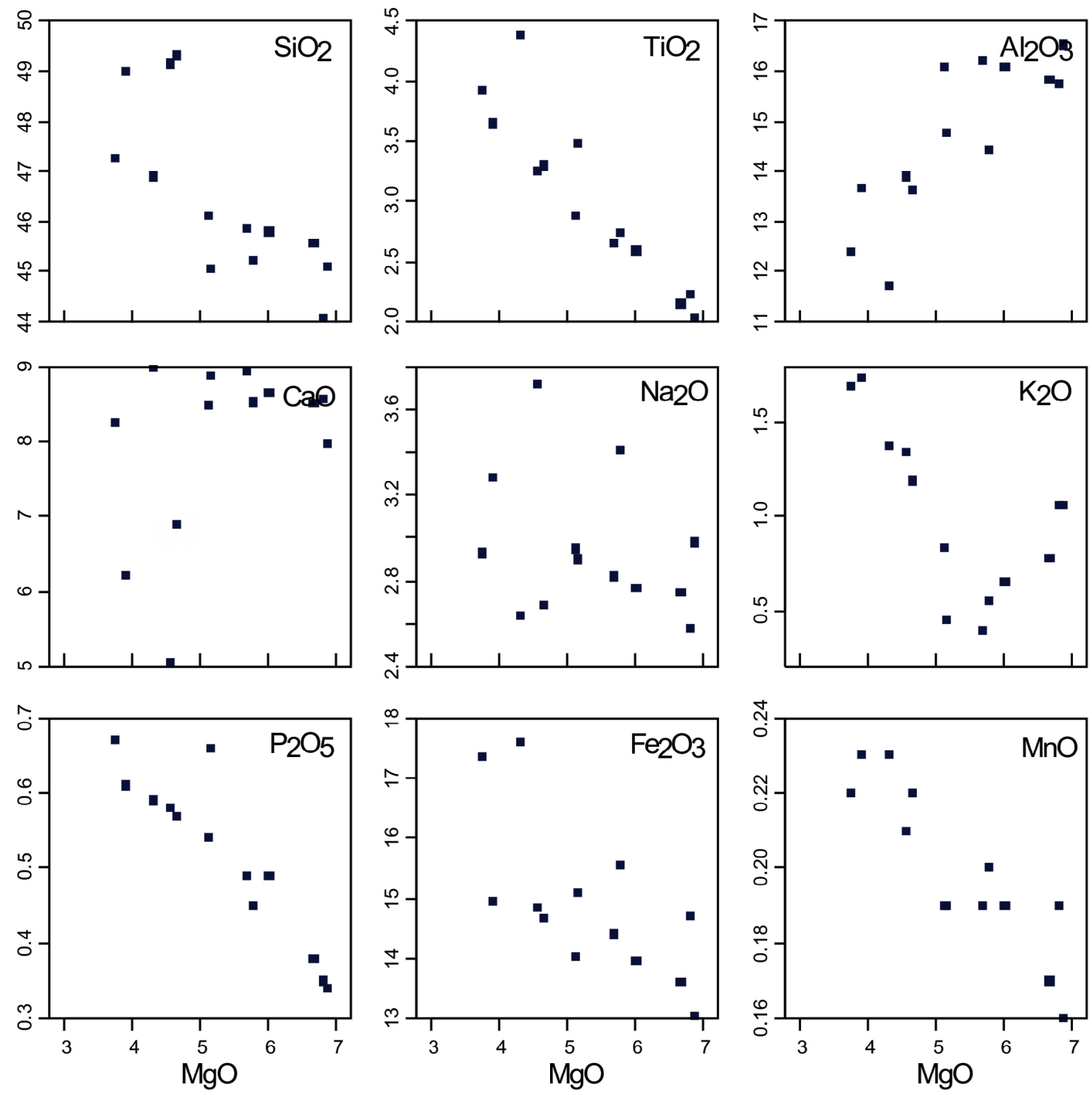

Figure 11. MgO variation diagrams versus major-elements (\% weight) for rocks from Salto do Céu Suite. 
from SCS overlap the domains proposed by these authors for continental intraplate basalts.

Pattern distribution of rare earth elements (REE) normalized to primitive mantle values of McDonough \& Sun (1995) is illustrated in Figure 14A. Heavy REE (HREE) fractionation relative to light REE (LREE) is observed. There is a clear distinction between the two rock groups in which one of them is richer in REE, with $\mathrm{La}_{\mathrm{N}}$ greater than 100 and a discrete negative Eu anomaly (group 1), corresponding to the rocks with lower $\mathrm{MgO}$ contents; the second group does not show this pattern having $\mathrm{La}_{\mathrm{N}}$ less than 100 (group 2). There is no relation between the shape of occurrence (sills and flows) with the groups of high and low LaN.

Figure $14 \mathrm{~B}$ shows a primitive-mantle normalized multi-element spidergram according to values of McDonough \& Sun (1995). Here rocks also show a separation into two groups, where the main difference is the negative $\mathrm{Sr}$ anomalies for the group with $\mathrm{La}_{\mathrm{N}}$ greater than 100 , and positive $\mathrm{Sr}$ anomalies for the group with $\mathrm{La}_{\mathrm{N}}$ less than 100, which corresponds to the group with discrete Eu anomaly. For other elements, both groups follow a very similar pattern with negative $\mathrm{Rb}, \mathrm{K}$, and $\mathrm{Nb}$ anomalies, and positive $\mathrm{Ti}$ anomaly likely reflecting no fractionation of Fe-Ti oxides. The negative $\mathrm{Nb}$ anomaly, in its turn, may be attributable to crustal assimilation processes.

\section{DISCUSSION AND FINAL CONSIDERATIONS}

Based on data from semi-detailed geological mapping as well as petrographic and lithochemical characterization, here we conclude the basic rocks from the region of Salto do Céu (Mato Grosso) occurring as sills and lava flows belong to the same magmatic event that gave rise to the Salto do Céu Suite. Moreover, the U-Pb baddeleyite age of $1439 \pm 4 \mathrm{Ma}$ (Teixeira et al. 2015), and geochronological dataset available for rocks from the Rio Branco Intrusive Suite $(1427 \pm 10 \mathrm{Ma}$, $1423 \pm 0.2 \mathrm{Ma}$ and $1423 \pm 6 \mathrm{Ma}$ obtained by Geraldes et al. 2001, 2004, Araújo 2008; respectively) indicate that both suites are derived from a bimodal coeval magmatism.

The temporal relation of Salto do Céu (mafic rocks) and Rio Branco (felsic rocks) suites is corroborated by the presence of magma mingling diagnostic features, such as mafic microgranular enclaves with alkali feldspar xenocrysts, diffuse and transitional boundaries and hybridization zones, as previously described. Moreover, oscillatory or reverse zoning in plagioclase can result from the interaction of felsic and mafic magmas. Ginibre et al. (2002) described zoning patterns in plagioclase crystals of the Parinacota Volcano (Chile) and assumed that this features can be generated by a magma chamber recharge with mafic magma.
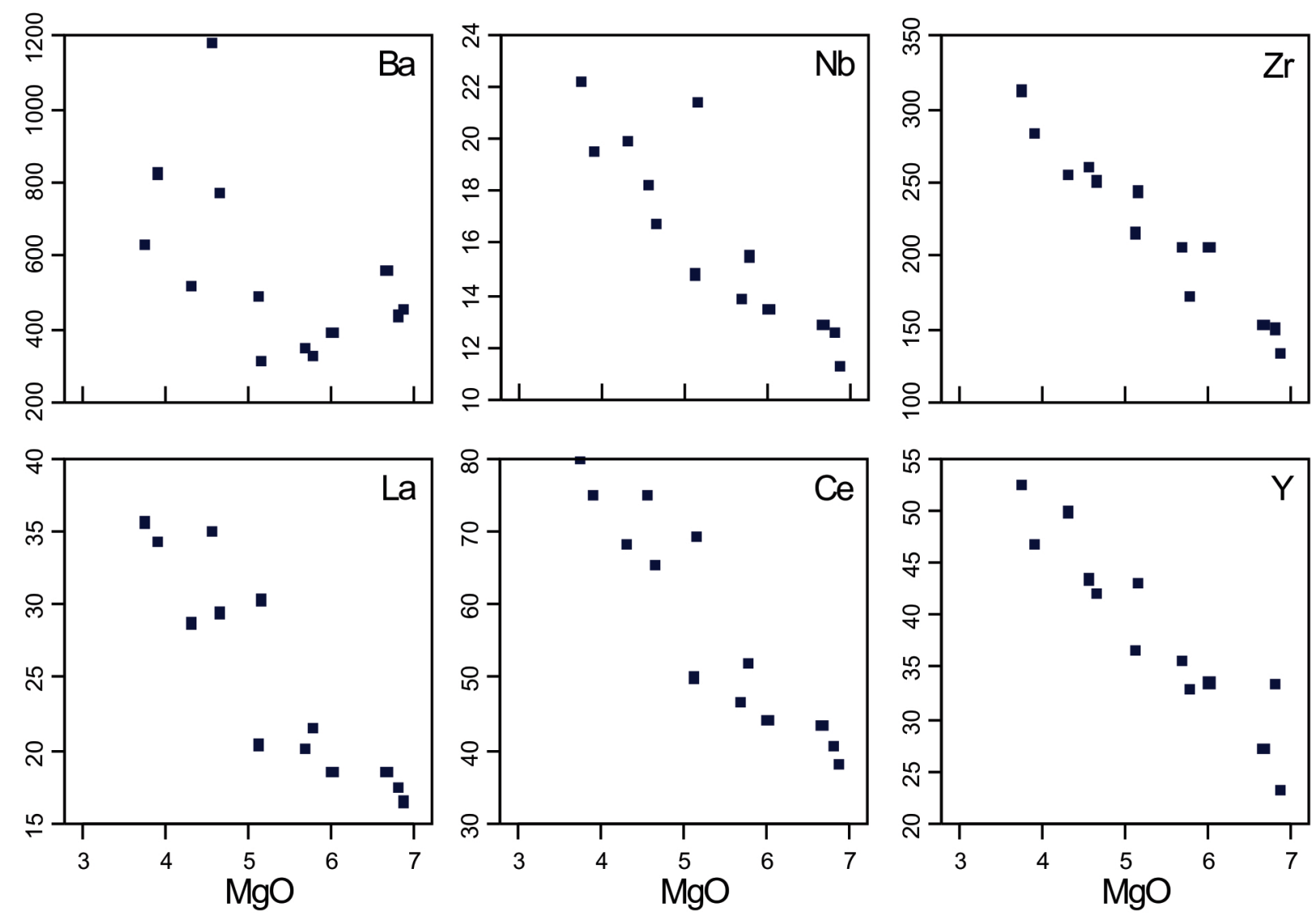

Figure 12. MgO variation diagrams (\% weight) versus trace-elements (ppm) for rocks from Salto do Céu Suite. 

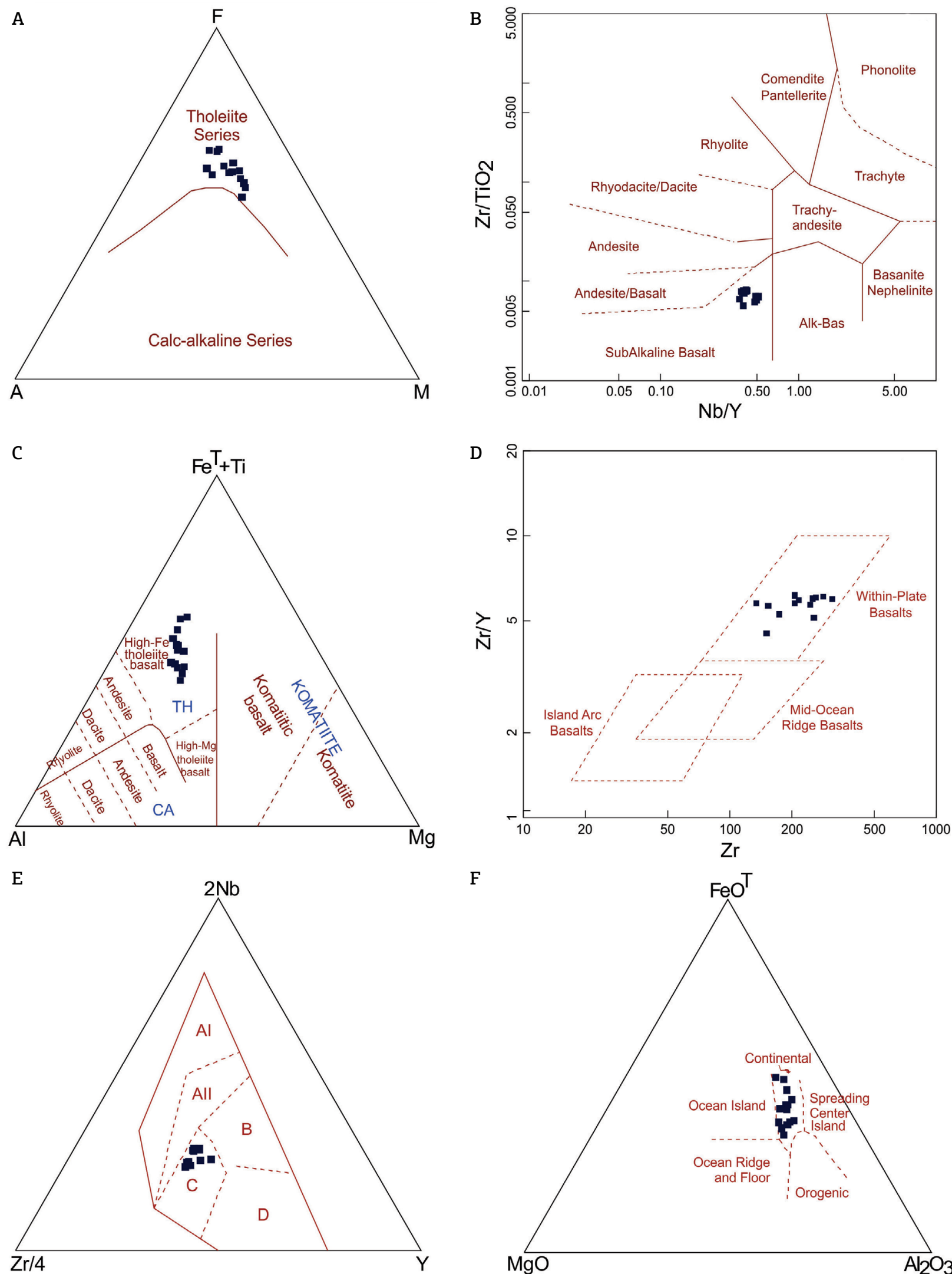

F

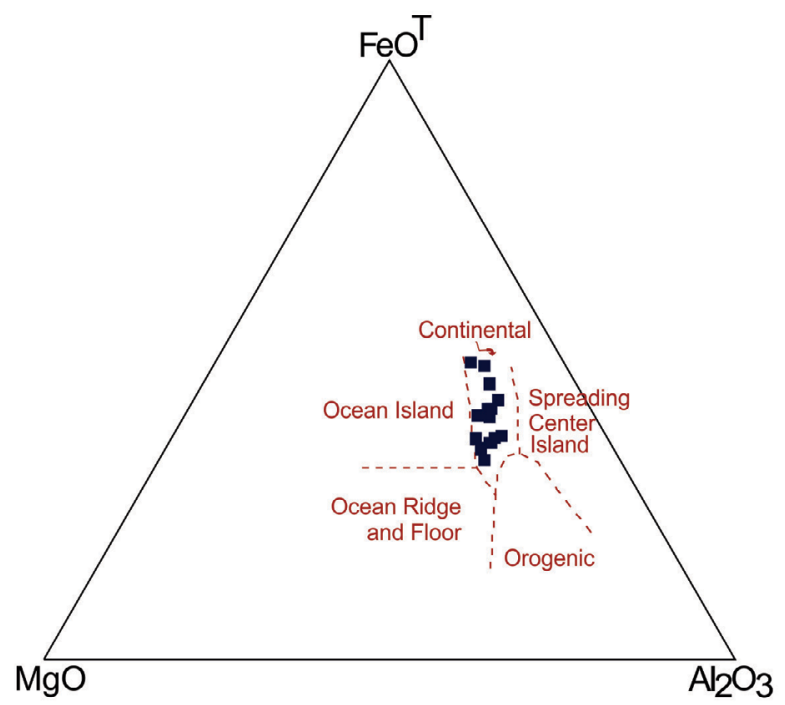

AI-AII: Within-Plate Alkaline Basalts; AII-C: Within-Plate Tholeiites; B: P-type Mid-Ocean Ridge Basalts; D: N-type Mid-Ocean Ridge Basalts; C-D: Volcanic Arc Basalt.

Figure 13. Classification diagrams for rocks from Salto do Céu Suite: (A) Irvine \& Baragar (1971); (B) Winchester \& Floyd (1977); (C) Jensen (1976); (D) Pearce \& Norry, (1979); (E) Meschede (1986); (F) Pearce et al. (1977). 

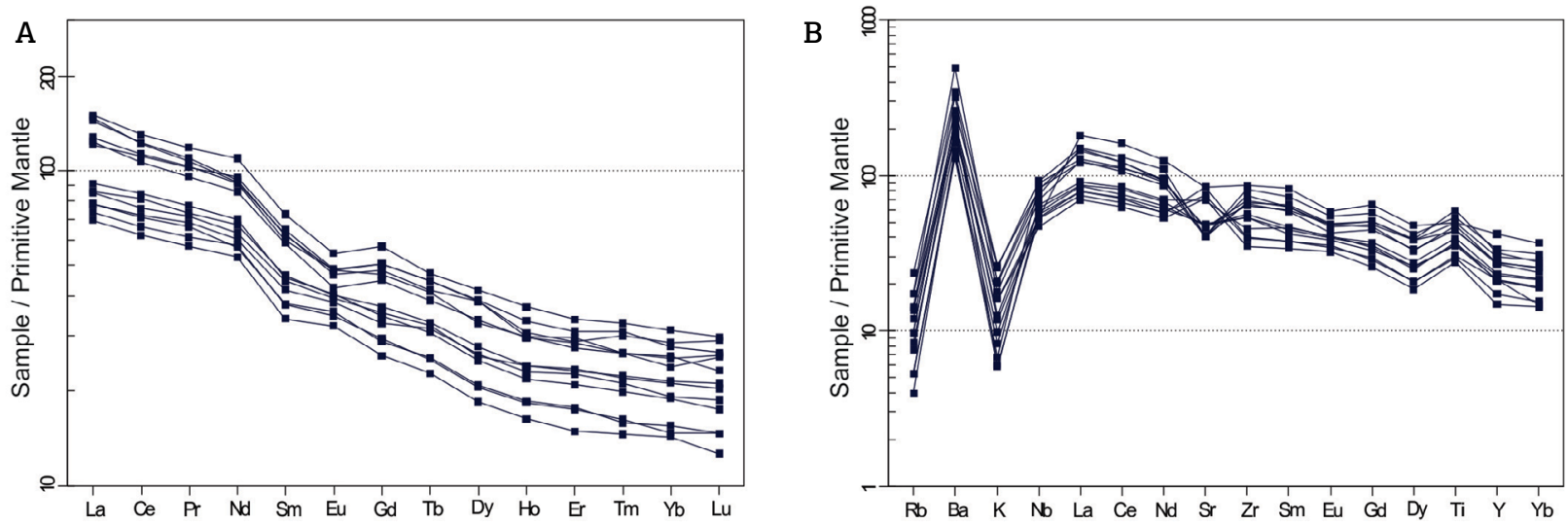

Figure 14. Rare earth elements (REE) (A) and multi-element spidergrams (B) normalized to primitive values of McDonough \& Sun (1995) for rocks from Salto do Céu Suite.

The TIMS U-Pb baddeleyite ages of $1110 \pm 2 \mathrm{Ma}$ and $1112 \pm 2$ Ma measured by Teixeira et al. (2015) for the mafic sills from Rincon del Tigre, respectively, in Bolivia and Huanchaca as well as that U-Pb baddeleyite age of $1439 \pm 4$ Ma obtained by Teixeira et al. (2016) for the basic magmatism of the Salto do Céu Suite, in Brazil, show that they are not related to a single igneous-tectonic event attributable to an older crustal extension episode that resulted in mantellic magma ascent, opposing previous proposals of Ruiz et al. (2010a), Lima et al. (2012), among others.

Geochronological data made available by Leite \& Saes (2003), Santos et al. (2005) and Geraldes et al. (2014) point out that the sedimentary cover hosting sills and lava flows of the Salto do Céu Suite is not attributable to the defined Aguapeí Group of the type-area in Santa Barbara Hill (Souza \& Hildred 1980).

The diagenesis of Fortuna Formation, basal unit of Aguapeí Group, occurred between $1165 \pm 27 \mathrm{Ma}$ and $1149 \pm 7 \mathrm{Ma}$ based on SHRIMP U-Pb dating of diagenetic xenotime from Santa Barbara Hill (Santos et al. 2005). A maximum deposition age of $1.3 \mathrm{Ga}$ on detrital zircons is attributed to it according to Leite \& Saes (2003; bottom of Aguapeí Group in São Vicente and Lavrinha hills) and Geraldes et al. (2014; Fortuna Formation in Ricardo Franco and Santa Barbara hills). The younger basement rocks of this group in the surrounding region are the post-kinematic granites of the Pensamiento Suite dated at 1290 Ma by U-Pb (LA-IPC-MS) (Jesus et al. 2010).

Geraldes et al. (2014) report a maximum deposition age around $1540 \mathrm{Ma}$ (U-Pb, LA-ICP-MS) for this group in the
Rio Branco Hill, which supports the notion that it is a different sedimentary cover, likely another stratigraphic unit deposited in the Calymmian once the younger rocks of the underlying basement consist of post-kinematic granites of the Alvorada Suite dated around $1440 \mathrm{Ma}$ by U-Pb (TIMS) on zircon (Geraldes et al. 2001, Ruiz 2005).

The mafic-ultramafic suites named Figueira Branca and Indiavaí (1.42 a $1.41 \mathrm{Ga}$; Teixeira et al. 2011) are part of the Jauru Terrane and are chrono-correlated to the Salto do Céu and Rio Branco suites as well as may be derived from a single magmatic event.

The mafic sills and lava flows from Salto do Céu Suite and the rocks from Rio Branco Suite are here interpreted as an anorogenic bimodal suite formed in intraplate settings, in extensive tectonic regime, which may reflect an important tectonic milestone associated with the breakup of the Columbia (Nuna) Supercontinent.

\section{ACKNOWLEDGEMENTS}

Authors gratefully acknowledge the financial support from CAPES (PROCAD 096/2007, National Program of Academic Cooperation), CNPq (process number 479779/2011-2, National Council for Scientific and Technological Development), FAPEMAT (process number 222473/2015, Foundation for Research Support of Mato Grosso), and GEOCIAM (National Institute of Sciences and Geoscience Technology of the Amazon). The first author acknowledges $\mathrm{CNPq}$ for granting the $\mathrm{PhD}$ scholarship.

\section{REFERENCES}

Araújo L.M.B. 2008. Evolução do magmatismo pós-cinemático do Domínio Cachoeirinha: Suites Intrusivas Santa Cruz, Alvorada e Rio Branco-SW do Cráton Amazônico-MT. PhD Thesis, Universidade Estadual Paulista "Júlio de Mesquita Filho", Rio Claro, $158 \mathrm{p}$.

Araújo L.M.B., Godoy A.M. 2011. Magmatismo o Batólito Rapakivi Rio Branco, SW do Cráton Amazônico (MT). Geociências, 30:173-195.
Araújo L.M.B., Godoy A.M., Ruiz A.S., Souza M.Z.A. 2005. Soleiras Máficas Tonianas (Suíte Intrusiva Salto do Céu) no SW do Cráton Amazônico: regime extensional relacionado à Orogenia Sunsás? In: Simpósio de Geologia do Centro-Oeste, Goiânia. Short Papers..., p. 155-156.

Araújo L.M.B., Godoy A.M., Zanardo A. 2009. As Rochas Básicas Intrusivas das Suítes Rio Branco e Salto Do Céu, na região de Rio Branco (MT) Sudoeste do Cráton Amazônico. Revista Brasileira de Geociências, 39:289-303. 
Araújo-Ruiz L.M.B., Godoy A.M., Ruiz A.S., Sousa M., Montano L 2007. Geologia e Geoquímica do Batólito Rapakivi Rio Branco, SW do Cráton Amazônico - MT. Geologia USP - Série Científica, 7:57-72. https://doi.org/10.5327/Z1519-874x2007000100005

Aubele J.C., Crumpler L.S., Elston W.E. 1988. Vesicle zonation and vertical structure of basalt flows. Journal of Volcanology and Geothermal Research, 35:349-374. https://doi. org/10.1016/0377-0273(88)90028-5

Barbarin B. 2005. Mafic magmatic enclaves and mafic rocks associated with some granitoids of the Sierra Nevada batholiths, California: nature, origin and relations with the hosts. Lithos, 80:155-177. https://doi.org/10.1016/j.lithos.2004.05.010

Barbarin B., Didier J. 1992. Genesis and evolution of mafic microgranular enclaves through various types of interaction between coexisting felsic and mafic magmas. Transactions of the Royal Society of Edinburgh Earth Sciences, 83:145-153. https://doi. org/10.1017/S0263593300007835

Barbey P., Gasquet D., Pin C., Bourgeix A.L. 2008. Igneous banding, schlieren and mafic enclaves in calc-alkaline granites: the Budduso pluton (Sardinia). Lithos, 104:147-163. http://dx.doi.org/10.1016/j. lithos.2007.12.004

Barros A.M., Silva R.H., Cardoso O.R.F.A., Freire F.A., Souza Jr. J.J., Rivetti M., Luz D.S., Palmeira R.C., Tassinari C.C.G. 1982. Folha SD.21. - Cuiabá. Rio de Janeiro, Ministério das Minas e Energia-Secretaria Geral, Projeto RADAMBRASIL

Bettencourt J.S., Leite Jr. W.B., Ruiz A.S., Matos R., Payolla B.L. Tosdal R.M. 2010. The Rondonian-San Ignacio Province in the SW Amazonian Cráton: An Overview. Journal of South American Earth Sciences, 29:28-46. http://dx.doi.org/10.1016/j.jsames.2009.08.006

Cashman K.V. \& Kauahikaua J.P. 1997. Reevaluation of vesicle distributions in basaltic lava flows. Geology, 25(5):419-422. https://doi.org/10.1130/0091-7613(1997)025\%3C0419:ROVDIB\% 3E2.3.CO;2

Chitwood L.A. 1994. Inflated basaltic lava - examples of processes and landform from central and southeast Oregon. Oregon Geology, 56(1):11-21.

Ernst R.E., Pereira E., Hamilton M.A., Pisarevsky S.A., Rodrigues J., Tassinari C.C.G., Teixeira W., Van-Dunem V. 2013. Mesoproterozoic intraplate magmatic 'barcode' record of the Angola portion of the Congo Craton: newlydated magmatic events at 1505 and $1110 \mathrm{Ma}$ and implications for Nuna (Columbia) supercontinent reconstructions. Precambrian Research, 230:103-118. http://doi. org/10.1016/j.precamres.2013.01.010

Ernst R.E., Wingate M.T.D., Buchan K.L., Li Z.X. 2008. Global record of 1600-700 Ma Large Igneous Provinces (LIPs): implications for the reconstruction of the pro-posed Nuna (Columbia) and Rodinia supercontinents. Precambrian Research, 160:159-178. http://dx.doi. org/10.1016/j.precamres.2007.04.019

Fettes D. \& Desmons J. (Eds.). 2008. Metamorphic rocks: a classification and glossary of terms. Cambridge, Cambridge University Press, 243 p.

Figueiredo A.J.A. \& Olivatti O. 1974. Projeto Alto Guaporé. Relatório Final Integrado. Goiânia, DNPM/CPRM, 173 p.

Geraldes M.C. 2000. Geocronologia e geoquímica do plutonismo mesoproterozoico do SW do Estado de Mato Grosso (SW do Cráton Amazônico). PhD Thesis, Universidade de São Paulo, São Paulo, 193 p.

Geraldes M.C., Bettencourt J.S., Teixeira W, Matos J.M. 2004. Geochemistry and isotopic constraints on the origin of the mesoproterozoic Rio Branco 'anorogenic' plutonic suite, SW of Amazonian craton, Brazil: high heat flow and crustal extension behind the Santa Helena arc? Journal of South American Earth Sciences, 17:195-208. https://doi.org/10.1016/j. jsames.2004.05.010
Geraldes M.C., Nogueira C., Vargas-Mattos G., Matos R., Teixeira W. Valencia V., Ruiz J. 2014. U-Pb detrital zircon ages from the Aguapei Group (Brazil): Implications for the geological evolution of the SW border of the Amazonian Craton. Precambrian Research, 244:306316. https://doi.org/10.1016/j.precamres.2014.02.001

Geraldes M.C., Van Schmus W.R., Condie K.C., Bell S., Teixeira W., Babinski M. 2001. Proterozoic geologic evolution of the SW part of the Amazonian Craton in Mato Grosso state, Brazil. Precambrian Research, 111:91-128. http://doi.org/10.1016/ S0301-9268(01)00158-9

Ginibre C., Wörner G., Kronz A. 2002. Minor- and trace-element zoning in plagioclase: implications for magma chambre processes at Parinacota volcano, northern Chile. Contributions to Mineralogy and Petrology, 143:300-315. https://doi.org/10.1007/s00410-002-0351-z

Hon K., Kauahikaua J., Denlinger R., MacKay K. 1994. Emplacement and inflation of pahoehoe sheet flows: observations and measurements of active lava flows on Kilauea Volcano, Hawaii. Geological Society America Bulletin, 106:351-370. https://doi. org/10.1130/0016-7606(1994)106\%3C0351:EAIOPS\%3E2.3.CO;2

Irvine I.N. \& Baragar W.R. A. 1971. A Guide To The Chemical Classification Of The Common Volcanics Rocks. Canadian Journal Earth Science, 8:523-548. https://doi.org/10.1139/e71-055

Janoušek V., Farrow C.M., Erban V. 2006. Interpretation of wholerock geochemical data in igneous geochemistry: introducing Geochemical Data Toolkit (GCDkit). Journal of Petrology, 47(6):12551259. https://doi.org/10.1093/petrology/egl013

Jaques A.L. \& Green D.H. 1979. Determination of liquid compositions in high pressure melting of peridotite. American Mineralogist, 64:1312-1321

Jaques A.L. \& Green D.H. 1980. Anhydrous melting of peridotite at $0-15 \mathrm{~kb}$ pressure and the genesis of tholeiitic basalts. Contributions to Mineralogy and Petrology, 73:287-310.

Jensen L.S. 1976. A new cation plot for classifying subalkalic volcanic rocks. Ontario, Ontario Division of Mines, Miscellaneous Paper 66, 22 p.

Jesus G.C., Sousa M.Z.A., Ruiz A.S., Matos J.B. 2010. Petrologia e geocronologia (U-Pb/Sm-Nd) do Granito Passagem, Complexo Granitoide Pensamiento, SW do Cráton Amazônico (MT). Revista Brasileira de Geociências, 40(3):392-408

LASA - Engenharia e Prospecções S.A. 1968. Levantamento fotogeológico e geoquímico do Centro-Oeste de Mato Grosso, Vale do Jauru e adjacências. Rio de Janeiro. Relatório Técnico do arquivo da DGM, 153. DNPM

Leite J.A.D. \& Saes G.S. 2003. Geocronologia Pb-Pb de zircões detríticos e análise estratigráfica das coberturas sedimentares proterozoicas do sudoeste do Cráton Amazônico. Geologia USP - Série Científica, 3(2):113-127. https://doi.org/10.5327/S1519-874X2003000100009

Leite J.A.D., Saes G.S., Weska R.K. 1985. A Suíte Intrusiva Rio Branco e o Grupo Aguapeí na serra de Rio Branco, Mato Grosso. In: Simpósio de Geologia do Centro-Oeste, Goiânia. Short Papers..., p. 247-255.

Lima G.A. 2011. Geologia, Geoquímica e Geocronologia dos sills máficos da Suíte Intrusiva Huanchaca na porção nordeste da Serra Ricardo Franco (MT) - SW do Cráton Amazônico. MS Dissertation, Instituto de Ciências Exatas e da Terra, Universidade Federal de Mato Grosso, Cuiabá, 62 p

Lima G.A., Sousa M.Z.A., Ruiz A.S., D’Agrella Filho M.S., Vasconcelos P. 2012. Sills máficos da Suíte Intrusiva Huanchaca - SW do Cráton Amazônico: registro de magmatismo fissural relacionado à ruptura do Supercontinente Rodínia. Revista Brasileira de Geociências, 42:111-129.

McDonough W.F. \& Sun S.S. 1995. The composition of the earth. Chemical Geology, 120:223-253. https://doi org/10.1016/0009-2541(94)00140-4 
Meschede M. 1986. A method of discriminating between different types of mid-ocean ridge basalts and continental tholeiites with the Nb-Zr-Y diagram. Chemical Geology, 56:207-218. https:/doi. org/10.1016/0009-2541(86)90004-5

Oliva L.A. 1979. Ocorrências Minerais na Folha Cuiabá (SD.21). Relatório de Viagem. Goiânia, DNPM, 18 p.

Pearce J.A. \& Norry M.J. 1979. Petrogenetic implications of Ti, Zr, Y and Nb variations Volcanic Rocks. Contributions to Mineralogy and Petrology, 69:33-47. https://doi.org/10.1007/BF00375192

Pearce T.H., Gorman B.E., Birkett T.C. 1977. The relationship between major element chemistry and tectonic environment of basic and intermediate volcanic rocks. Earth and Planetary Science Letters, 36:121-132. https://doi.org/10.1016/0012-821X(77)90193-5

Rogers J.J.W. \& Santosh M. 2002. Configuration of Columbia, a mesoproterozoic supercontinent. Gondwana Research, 5:5-22. https://doi.org/10.1016/S1342-937X(05)70883-2

Ruiz A.S. 1992. Contribuição a Geologia do Distrito de Cachoeirinha, MT. São Paulo. MS Dissertation, Instituto de Geociências, Universidade de São Paulo, São Paulo, 98 p.

Ruiz A.S. 2005. Evolução Geológica do Sudoeste do Cráton Amazônico Região Limitrofe Brasil-Bolívia - Mato Grosso. PhD Thesis, Universidade Estadual Paulista "Júlio de Mesquita Filho", Rio Claro, 250 p.

Ruiz A.S., D’Agrella Filho M.S., Sousa M.Z.A., Lima G.A. 2010a. Tonian sills and mafic dike swarms of S-SW Amazonian Cráton: records of Rodinia Supercontinent break-up? In: The Meeting of the Americas, 1., Foz do Iguaçu. Short Papers...

Ruiz A.S., Matos J.B., Sousa M.Z.A., Lima G.A., Batata M.E.F. 2010b. Mapeamento Geológico e Levantamento de Recursos Minerais da Folha Santa Bárbara (SD.21-Y-C-V). Convênio CPRM-UFMT. Brasil, Programa Geologia do Brasil, Relatório Etapa de Mobilização, 35 p.

Saes G.S. 1999. Evolução Tectônica e Paleogeográfica do Aulacógeno Aguapeí (1.2 - $1.0 \mathrm{Ga}$ ) e dos Terrenos do seu embasamento na porção sul do Cráton Amazônico. PhD Thesis, Universidade de São Paulo, São Paulo, 135 p.

Santos J.O.S., McNaughton N.J., Hartmann L.A., Fletcher I.R., Salinas R.M. 2005. The age of deposition of the Aguapeí Group, Western Amazon Craton, based on $\mathrm{U}-\mathrm{Pb}$ study of diagenetic xenotime and detrital zircon. In: Latin American Geological Congress, Quito. Short Papers..., p. 1-4.
Sécolo D.B., Ruiz A.S., Sousa M.Z.A., Lima G.A. 2011. Geologia, Petrografia e Geoquímica do Enxame de Diques Máficos da região de Vila Bela da Santíssima Trindade (MT) Suíte Intrusiva Huanchaca SW do Cráton Amazônico. Geociências, 30:561-573.

Self S., Keszthelyi L., Thordason T. 1998. The importance of pahoehoe. Annual Review Earth Planetary Science, 26:81-110. https://doi. org/10.1146/annurev.earth.26.1.81

Sousa M.Z.A., Batata M.E.F., Ruiz A.S., Lima G.A., Matos J.B., Paz J.D.S., Costa A.C.D., Silva C.H., Corrêa da Costa P.C. 2017. Geologia da Folha Rio Branco (SD21-Y-D-I). Brasil, Ministério das Minas e Energia, Programa Nacional de Geologia (PRONAGEO), CPRM/ UFMT, $178 \mathrm{p}$.

Souza E.P. \& Hildred P.R. 1980. Contribuição ao estudo da geologia do Grupo Aguapeí, Oeste de Mato Grosso. In: Congresso Brasileiro de Geologia, Camboriú. Short Papers..., p. 813-825.

Takahashi E. \& Kushiro I. 1983. Melting of dry peridotite at high pressures and basalt magma genesis. American Mineralogist, 68:859-879

Teixeira W., Ernst R., Hamilton M.A., Lima G., Ruiz A.S., Geraldes M.C. 2016. Widespread ca. $1.4 \mathrm{Ga}$ intraplate magmatism and tectonics in a growing Amazonia. GFF (Uppsala), 1:241-254. https://doi.org/10.1 080/11035897.2015.1042033

Teixeira W., Geraldes M.C., D’Agrella-Filho M.S., Santos J.O.S., Sant'Ana Barros M.A., Ruiz A.S., Corrêa da Costa P.C. 2011. Mesoproterozoic juvenile mafic-ultramafic magmatism in the SW Amazonian Craton (Rio Negro-Juruena province): SHRIMP U-Pb geochronology and $\mathrm{Nd}-\mathrm{Sr}$ constraints of the Figueira Branca Suite. Journal of South American Earth Sciences, 32:309-323.

Teixeira W., Hamilton M.A., Lima G.A., Ruiz A.S., Matos R., Erns, R.E. 2015. Precise ID-TIMS U-Pb baddeleyite ages (1110-1112Ma) for the Rincón del Tigre-Huanchaca large igneous province (LIP) of the Amazonian Craton: Implications for the Rodinia supercontinent. Precambrian Research, 265:273-285. https://doi.org/10.1016/j. precamres.2014.07.006

Winchester J.A. \& Floyd P.A. 1977. Geochemical discrimination of different magma series and their differentiation products using immobile elements. Chemical Geology, 20:325-343. https://doi. org/10.1016/0009-2541(77)90057-2 